\title{
Review Article \\ Sensors Applied for the Detection of Pesticides and Heavy Metals in Freshwaters
}

\author{
Hongyong Xiang $\mathbb{D}^{1,2}$ Qinghua Cai, ${ }^{3}$ Yuan Li $\mathbb{D}^{4},{ }^{4}$ Zhenxing Zhang $\mathbb{D}^{1,5}$ Lina Cao, ${ }^{6}$ Kun Li, \\ and Haijun Yang ${ }^{1,2,8}$
}

${ }^{1}$ Key Laboratory of Vegetation Ecology, Ministry of Education, Institute of Grassland Science, Northeast Normal University, Changchun, Jilin 130024, China

${ }^{2}$ Institute for Ecological Research and Pollution Control of Plateau Lakes, School of Ecology and Environmental Science, Yunnan University, Kunming, Yunnan 650500, China

${ }^{3}$ State Key Laboratory of Freshwater Ecology and Biotechnology, Institute of Hydrobiology, Chinese Academy of Sciences, Wuhan 430072, China

${ }^{4}$ Northwest Land and Resources Research Center, Shaanxi Normal Northwest University, China

${ }^{5}$ State Environmental Protection Key Laboratory of Wetland Ecology and Vegetation Restoration, Northeast Normal University, Changchun, Jilin 130024, China

${ }^{6}$ Ecology and Environment Department of Jilin Province, Changchun, Jilin 130024, China

${ }^{7}$ Heilongjiang Provincial Key Laboratory of Ecological Restoration and Resource Utilization for Cold Region, Heilongjiang University, Harbin 150080, China

${ }^{8}$ School of Life Science and Geology, Yili Normal University, Yili, Xinjiang 835000, China

Correspondence should be addressed to Zhenxing Zhang; zhangzx725@nenu.edu.cn and Haijun Yang; yang@nenu.edu.cn

Received 29 October 2019; Accepted 20 January 2020; Published 11 February 2020

Academic Editor: Alberto J. Palma

Copyright (c) 2020 Hongyong Xiang et al. This is an open access article distributed under the Creative Commons Attribution License, which permits unrestricted use, distribution, and reproduction in any medium, provided the original work is properly cited.

Water is essential for every life living on the planet. However, we are facing a more serious situation such as water pollution since the industrial revolution. Fortunately, many efforts have been done to alleviate/restore water quality in freshwaters. Numerous sensors have been developed to monitor the dynamic change of water quality for ecological, early warning, and protection reasons. In the present review, we briefly introduced the pollution status of two major pollutants, i.e., pesticides and heavy metals, in freshwaters worldwide. Then, we collected data on the sensors applied to detect the two categories of pollutants in freshwaters. Special focuses were given on the sensitivity of sensors indicated by the limit of detection (LOD), sensor types, and applied waterbodies. Our results showed that most of the sensors can be applied for stream and river water. The average LOD was $72.53 \pm 12.69 \mathrm{ng} / \mathrm{ml}(n=180)$ for all pesticides, which is significantly higher than that for heavy metals $(65.36 \pm 47.51 \mathrm{ng} / \mathrm{ml}, n=117)$. However, the LODs of a considerable part of pesticides and heavy metal sensors were higher than the criterion maximum concentration for aquatic life or the maximum contaminant limit concentration for drinking water. For pesticide sensors, the average LODs did not differ among insecticides $(63.83 \pm 17.42 \mathrm{ng} / \mathrm{ml}, n=87)$, herbicides $(98.06 \pm 23.39 \mathrm{ng} / \mathrm{ml}, n=71)$, and fungicides $(24.60 \pm 14.41 \mathrm{ng} / \mathrm{ml}, n=22)$. The LODs that differed among sensor types with biosensors had the highest sensitivity, while electrochemical optical and biooptical sensors showed the lowest sensitivity. The sensitivity of heavy metal sensors varied among heavy metals and sensor types. Most of the sensors were targeted on lead, cadmium, mercury, and copper using electrochemical methods. These results imply that future development of pesticides and heavy metal sensors should (1) enhance the sensitivity to meet the requirements for the protection of aquatic ecosystems and human health and (2) cover more diverse pesticides and heavy metals especially those toxic pollutants that are widely used and frequently been detected in freshwaters (e.g., glyphosate, fungicides, zinc, chromium, and arsenic). 


\section{Introduction}

Seventy-one percent of our planet is covered by water which is a vital necessity to the organisms living on the earth. Even though freshwater only occupied less than $3 \%$ of all the water on earth, our daily life is more associated with freshwater than saltwater. However, many freshwater ecosystems have been polluted by anthropogenic activities including the three most dominating contributors: human settlements, industries, and agriculture [1-3]. For example, more than 100,000 chemicals (e.g., pesticides) are registered nowadays, and most of them are related to our daily life; these chemicals can inevitably enter freshwaters [4]. In addition, more than half of the total production of chemicals is harmful to the environment [5]. In Latin America, Africa, and Asia, 1/3, $1 / 7$, and $1 / 10$ of all the streams and rivers have already been affected by pathogen (e.g., fecal coliform bacteria), organic (e.g., biochemical oxygen demand (BOD)), and salinity (e.g., total dissolved solids (TDS)) pollution [6]. At a national scale survey, the water quality of $\sim 1 / 3$ of US' streams and rivers was assessed by the Environmental Protection Agency (EPA), and the results revealed that $55 \%$ of the streams were categorized as impaired. Bacteria, sediment, and nutrients were identified as the three most significant causes for stream pollution in this survey [7]. Freshwaters in developing countries such as China are facing more serious pollution situation. It was estimated that $\sim 60 \%$ of China's groundwater was classified as poor or very poor, and the number is even higher $(\sim 80 \%)$ in 17 northern provinces [8]. The impaired water quality negatively affected aquatic organisms and generates major threats to waterbodies, with great consequences on aquatic ecosystems at levels ranging from individuals to watershed [9-13]. More importantly, human health is also at risk if clean drinking water cannot be accessed [4]. It was estimated that the freshwater resources for $82 \%$ of the world's population are under high levels of threats, and the situation is more serious in developing countries than in developed countries [14]. Consequently, more than $1 / 3$ of the population in the world lacks safe drinking water [4]. Freshwaters (e.g., streams, rivers, lakes, and ponds) receive large quantity of various pollutants including pesticides [15], heavy metals [16], and nutrients [17]. It was estimated that $80 \%$ of municipal wastewater that flows into waterbodies is untreated, and millions of tonnes of heavy metals and other pollutants were dumped into waterbodies every year [18]. In China, human activities introduced $14.5 \pm 3.1$ mega tonnes of nitrogen to freshwaters each year which are 2.7 times of the predicted safety threshold [19]. Excess nutrients such as nitrogen and phosphorus in freshwaters usually lead to eutrophication, one of the most common reasons for water quality degradation [20, 21]. Many efforts have been done to improve the water quality of freshwaters via direct or indirect ways $[22,23]$. Monitoring water quality in freshwaters is still the first priority for many ecological studies, water quality control, and restoration projects [24, 25].

Monitoring water quality is especially important for the provision of clean drinking water and the protection of aquatic ecosystems $[26,27]$. After the development of decades, numerous kinds of sensors, including chemical sensors, biosensors, and electronical sensors, have been developed to detect water quality $[28,29]$. A sensor is a device that is capable of providing selective quantitative or semiquantitative analytical information via a biologi$\mathrm{cal} / \mathrm{chemical} /$ electronical recognition element; it usually is composed of a transducer and a processor [30]. Generally, the requirements of water quality sensors are confined to many factors such as the waterbodies to be monitored, water quality parameters to be tested, and the objects of the monitoring system [31]. The projection of future sensors targets on higher sensitivity, rapider detection, smaller size, inexpensiveness, disposability, ease of manipulation, durability for longer time, and suitability for multiple environments. For example, in a newly published review, Parra et al. [29] summarized several requirements of physical sensors for precision aquaculture: low maintenance, low cost, low battery consumption, nonmetal, robust, waterproof, withstand biofouling, and no effects on aquatic organisms. Previous review papers focus on either one type/category of sensors [32] or one analyte (or one group of analytes) [33]. This review paper will focus on the sensors applied to test two of the most common pollutants in freshwaters, i.e., pesticides and heavy metals. The general contamination status of these parameters in freshwaters and a simple analysis of sensors are also discussed. The sensitivity of sensors (limit of detection (LOD)) and sensor types are especially discussed. The present review paper differs from previous review papers in the following ways: (1) we unified the unit of LOD to make the comparison between studies possible and visualized; (2) only the data collected from freshwaters were used; and (3) not only the sensor types but also the detected analyte categories were discussed.

\section{Materials and Methods}

2.1. Database Compilation. We build the database of pesticide sensors by searching Web of Science using the following topics: "sensor" and "pesticide or herbicide or fungicide or insecticide" and "freshwater or river or stream or lake or reservoir or pond". Most of the collected papers were published during the last five years which composed almost half of the publications (2015-2019). The data collected before 2015 were mainly based on previous review papers [34-36]. For each publication, we extracted the following information: tested analytes, sensor types (e.g., biosensors and electronical sensors), LODs, and the applicable waterbodies. For the optical sensors, we included fluorescent sensors, luminescent sensors, and colorimetric sensors. The tested analytes were grouped into three categories of pesticides (i.e., herbicides, insecticides, and fungicides). All the units of LODs were unified as $\mathrm{ng} / \mathrm{ml}$. The same method was used to build the database of heavy metal sensors by replacing "pesticide OR herbicide OR fungicide OR insecticide" with "heavy metal". For heavy metal sensors, we only collected data during the year 2017-2019 (updated until October) which composed $\sim 1 / 3$ of all the publications. 
TABLE 1: Summary of studies employing sensors for the detection of pesticides in freshwaters.

\begin{tabular}{|c|c|c|c|c|}
\hline Analytes & Sensor types & LOD (ng/ml) & Waterbodies & Ref. \\
\hline Picloram & Bioelectrochemical & 5 & Paddy field water & {$[55]$} \\
\hline Malathion & Biosensor & 1 & Tap water & {$[56]$} \\
\hline Methamidophos & Biosensor & $\begin{array}{c}0.01 \\
0.013\end{array}$ & $\begin{array}{l}\text { Tap water } \\
\text { River water }\end{array}$ & [57] \\
\hline $\begin{array}{l}\text { Monocrotophos } \\
\text { Mevinphos } \\
\text { Phosphamidon } \\
\text { Omethoate }\end{array}$ & Biosensor & $\begin{array}{l}0.015 \\
0.009 \\
0.012 \\
0.032\end{array}$ & River and tap water & [58] \\
\hline Bentazone & Electronical & 262.3 & River water & [59] \\
\hline $\begin{array}{l}\text { Carbaryl } \\
\text { Heptenophos } \\
\text { Fenitrothion }\end{array}$ & Electrochemical & $\begin{array}{l}5.3 \\
3.6 \\
160\end{array}$ & Wastewater & {$[60]$} \\
\hline $\begin{array}{l}\text { Carbofuran } \\
\text { Fenobucarb }\end{array}$ & Electronical & $\begin{array}{l}2 \\
2\end{array}$ & Tap water and farmland water & [61] \\
\hline $\begin{array}{l}\text { Paraoxon } \\
\text { Carbaryl }\end{array}$ & Bioelectronical & $\begin{array}{l}2.8 \\
8.0\end{array}$ & Lagoon water & [62] \\
\hline $\begin{array}{l}\text { Chlorpyrifos } \\
\text { Chlorfenvinfos }\end{array}$ & Biosensor & $\begin{array}{l}0.004 \\
0.004\end{array}$ & Lake water & [63] \\
\hline Atrazine & Electrochemical & 2.2 & River water & [64] \\
\hline Atrazine & Electrochemical & 4.5 & River water & [65] \\
\hline Atrazine & Electrochemical & 1.9 & River water & [66] \\
\hline Atrazine & Electrochemical & 13 & River water & [67] \\
\hline $\begin{array}{l}\text { Atrazine } \\
\text { Ametryne }\end{array}$ & Electrochemical & $\begin{array}{l}3.1 \\
3.8\end{array}$ & River water & [68] \\
\hline Atrazine & Electrochemical & 30.2 & Natural waters & [69] \\
\hline $\begin{array}{l}\text { Chlorpyrifos oxon } \\
\text { Paraoxon } \\
\text { Malaoxon }\end{array}$ & Bioelectronical & $\begin{array}{l}1.1 \\
30 \\
25\end{array}$ & River water & {$[70]$} \\
\hline Chlormequat & Bioelectronical & 502.74 & River and ground water & {$[71]$} \\
\hline $\begin{array}{l}\text { Carbofuran } \\
\text { Carbaryl }\end{array}$ & Bioelectronical & $\begin{array}{c}20 \\
300\end{array}$ & Well water & {$[72]$} \\
\hline $\begin{array}{l}\text { Paraoxon } \\
\text { Methyl parathion }\end{array}$ & Bioelectronical & $\begin{array}{l}5.5 \\
5.8\end{array}$ & Well water & [73] \\
\hline Omethoate & Bioelectronical & 21.3 & Lake water & {$[74]$} \\
\hline Atrazine & Biooptical & 0.15 & $\begin{array}{l}\text { Drinking, lake, and } \\
\text { agricultural wastewater }\end{array}$ & {$[75]$} \\
\hline Isoproturon & Bio-Opt & 3 & Well water & [76] \\
\hline Carbaryl & Biooptical & 0.029 & Drinking water & {$[77]$} \\
\hline $\begin{array}{l}\text { Carbendazim } \\
\text { Carbofuran } \\
\text { Benomyl }\end{array}$ & Biooptical & $\begin{array}{l}15 \\
68 \\
35\end{array}$ & Environmental water & {$[78]$} \\
\hline Carbaryl & Biooptical & 0.27 & River water & [79] \\
\hline $\begin{array}{l}\text { Fuberidazole } \\
\text { Carbaryl } \\
\text { Benomyl }\end{array}$ & Biooptical & $\begin{array}{c}0.09 \\
6 \\
9\end{array}$ & River, well, dam, irrigation water & {$[80]$} \\
\hline $\begin{array}{l}\text { Fuberidazole } \\
\text { O-Phenylphenol }\end{array}$ & Biooptical & $\begin{array}{c}0.18 \\
6.1\end{array}$ & River and well water & [81] \\
\hline Linuron & Biooptical & 130 & $\begin{array}{l}\text { Tap, underground, } \\
\text { mineral, and river water }\end{array}$ & {$[82]$} \\
\hline Metsulfuron methyl & Optical & 0.14 & River, well, and irrigation water & [83] \\
\hline
\end{tabular}


TABle 1: Continued.

\begin{tabular}{|c|c|c|c|c|}
\hline Analytes & Sensor types & $\mathrm{LOD}(\mathrm{ng} / \mathrm{ml})$ & Waterbodies & Ref. \\
\hline$\alpha$-Naphthol & & 2 & & \\
\hline O-Phenylphenol & Optical & 2 & Tap and river water & {$[84]$} \\
\hline Thiabendazole & & 2 & & \\
\hline Triazine & Biooptical & 0.0013 & River water & {$[85]$} \\
\hline Thiabendazole & Optical & 2.8 & $\begin{array}{l}\text { Tap, underground, } \\
\text { mineral, and river water }\end{array}$ & {$[86]$} \\
\hline Warfarin & Optical & 2 & River, lake, and spring water & [87] \\
\hline $\begin{array}{l}\text { Thiabendazole } \\
\text { Metsulfuron methyl }\end{array}$ & Optical & $\begin{array}{l}2.5 \\
3.3\end{array}$ & Well, river, and irrigation water & {$[88]$} \\
\hline N-1-Naphthylphthlamic acid & Ontical & 8.1 & Drinking and mineral water & {$[89]$} \\
\hline 1-Naphthylamine & Uptical ty t t t & 11.2 & 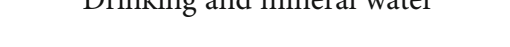 & {$[0]$} \\
\hline Thiabendazole & Optical & 4.5 & $\begin{array}{l}\text { Tap, underground, } \\
\text { mineral, and river water }\end{array}$ & {$[90]$} \\
\hline Carbaryl & Biooptical & 1.38 & Groundwater, tap, and river water & [91] \\
\hline 1-Naphthylamine & Optical & 1.1 & Well, tap, and urban wastewater & [92] \\
\hline Paraquat & Optical & 0.11 & Tap, well, lake, river, and rain water & [93] \\
\hline Paraquat & Optical & 1.6 & Wastewater & [94] \\
\hline Paraquat & Optical & 0.003 & Tap, mineral, waste, and ground water & [95] \\
\hline Paraquat & Optical & 0.7 & Drinking water & [96] \\
\hline Paraquat & Bioelectrochemical & 0.926 & River and groundwater & [97] \\
\hline Paraquat & Biooptical & 0.036 & River water & [98] \\
\hline Paraquat & Electronical & 23.92 & River water & [99] \\
\hline Paraquat & Electronical & 2 & Dam, river, and tap water & [100] \\
\hline Paraquat & Optical & 22 & River, dam, and mineral water & [101] \\
\hline $\begin{array}{l}\text { Paraquat } \\
\text { Diquat }\end{array}$ & Ele-optical & $\begin{array}{l}0.1 \\
0.2\end{array}$ & River water & [102] \\
\hline $\begin{array}{l}\text { Paraquat } \\
\text { Diquat }\end{array}$ & Ele-optical & $\begin{array}{l}0.2 \\
0.1\end{array}$ & $\begin{array}{l}\text { Tap, lake, river, } \\
\text { ground, and bog water }\end{array}$ & [103] \\
\hline $\begin{array}{l}\text { Paraquat } \\
\text { Diquat }\end{array}$ & Ele-optical & $\begin{array}{l}5 \\
1\end{array}$ & & [104] \\
\hline $\begin{array}{l}\text { Dipterex } \\
\text { Dursban }\end{array}$ & & $\begin{array}{l}5.152 \\
7.012\end{array}$ & & \\
\hline Paraquat & Che-optical & 5.143 & Wastewater & [105] \\
\hline Methyl thiophanate & & 6.84 & & \\
\hline Cartap & & 5.476 & & \\
\hline Paraoxon & Optical & 0.05 & Tap and river water & [106] \\
\hline Diniconazole & Biooptical & 6.4 & River and wastewater & [107] \\
\hline Diuron & Electrochemical & 0.00125 & Lake water & [108] \\
\hline $\begin{array}{l}\text { Diazinon } \\
\text { Iprobenfos } \\
\text { Edifenphos }\end{array}$ & Biooptical & $\begin{array}{l}36.3 \\
53.6 \\
27.9\end{array}$ & River water & [109] \\
\hline $\begin{array}{l}\text { Paraoxon } \\
2,4-\mathrm{D} \\
\text { Atrazine }\end{array}$ & Bioelectronical & $\begin{array}{c}2 \\
50 \\
10\end{array}$ & River water & [110] \\
\hline Diazinon & Bioelectrochemical & 0.039 & $\begin{array}{c}\text { Tap and } \\
\text { river wastewater }\end{array}$ & [111] \\
\hline Metamitron & Electrochemical & 7.28 & River water & [112] \\
\hline Carbamate & Biooptical & 3.3 & Lake water & [113] \\
\hline Diuron & Bioelectrochemical & 2.1 & River water & [114] \\
\hline Mesotrione & Electrochemical & 8.822 & Lake and tap water & [115] \\
\hline Paraquat & Electrochemical & 3.086 & River water & [116] \\
\hline Fenoxanil & Electronical & 0.0092 & River water & [117] \\
\hline
\end{tabular}


TABle 1: Continued.

\begin{tabular}{|c|c|c|c|c|}
\hline Analytes & Sensor types & LOD (ng/ml) & Waterbodies & Ref. \\
\hline Malathion & & 0.01 & \multirow{4}{*}{ Tap and river water } & \multirow{4}{*}[118]{} \\
\hline Parathion methyl & Bioelectrochemical & 0.02 & & \\
\hline Monocrotophos & Bioelectrochemical & 0.01 & & \\
\hline Dichlorvos & & 0.01 & & \\
\hline Dicloran & Bioelectrochemical & 0.099 & Tap and river water & [119] \\
\hline Fenitrothion & Electrochemical & 0.036 & Tap and lake water & {$[120]$} \\
\hline Carbamate & Optical & 0.023 & River water & {$[121]$} \\
\hline Fenoxycarb & Biooptical & 949.221 & River water & {$[122]$} \\
\hline Malathion & Ele-optical & 0.0991 & Pond water & {$[123]$} \\
\hline Methomyl & Electronical & 126.192 & River and tap water & {$[124]$} \\
\hline Diuron & \multirow{3}{*}{ Electronical } & 8.1585 & \multirow{3}{*}{ Lake and well water } & \multirow{3}{*}[125]{} \\
\hline $2,4-\mathrm{D}$ & & 26.405 & & \\
\hline Tebuthiuron & & 77.625 & & \\
\hline Pyrethroids & Biooptical & 42.64 & River water & {$[126]$} \\
\hline $2,4-\mathrm{D}$ & Electronical & 44.008 & River water & {$[127]$} \\
\hline Fomesafen & Electrochemical & 89 & Lake water & {$[128]$} \\
\hline Glyphosate & \multirow{15}{*}{ Biooptical } & 338 & \multirow{15}{*}{ Lake water } & \multirow{15}{*}[50]{} \\
\hline Dimethoate & & 458.52 & & \\
\hline Atrazine & & 431.36 & & \\
\hline Cyanazine & & 481.39 & & \\
\hline Diuron & & 466.2 & & \\
\hline Imidacloprid & & 511.32 & & \\
\hline Malathion & & 660.72 & & \\
\hline Imazethapyr & & 578 & & \\
\hline Mecoprop-P & & 429.3 & & \\
\hline $2,4-\mathrm{D}$ & & 440.08 & & \\
\hline Trifluralin & & 670.56 & & \\
\hline Paraquat & & 514.32 & & \\
\hline Metolachlor & & 567.6 & & \\
\hline Carbaryl & & 402.44 & & \\
\hline Acephate & & 366 & & \\
\hline Dichlorophen & Electronical & 3.768 & River water & {$[129]$} \\
\hline Hexazinone & Bioelectronical & 0.00066 & River water & {$[130]$} \\
\hline Malathion & Optical & $1.84 \times 10^{-7}$ & Agricultural runoff water and lake water & {$[131]$} \\
\hline Fenitrothion & Optical & 1.677 & Well, river, and tap water & {$[132]$} \\
\hline Pendimethalin & Electronical & 10.408 & Tap and river water & {$[133]$} \\
\hline $\begin{array}{l}\text { Metol } \\
\text { Bisphenol A }\end{array}$ & Electrochemical & $\begin{array}{l}0.344 \\
0.685\end{array}$ & River water & {$[134]$} \\
\hline Azinphos methyl & Che-optical & 0.549 & Tap and river water & {$[135]$} \\
\hline Fenvalerate pyrethroid & Optical & 0.01 & $\begin{array}{c}\text { Tao, river, well, } \\
\text { distilled, and draining water }\end{array}$ & {$[136]$} \\
\hline Propham & Electrochemical & 0.789 & River water & {$[137]$} \\
\hline Propham & Electrochemical & 0.179 & River water & {$[138]$} \\
\hline Cyanazine & Electrochemical & 0.06 & Tap, river, and ground water & {$[139]$} \\
\hline Tau-fluvalinate & Biooptical & 6.105 & Lake water & {$[140]$} \\
\hline Methyl parathion & Optical & 291.3 & Lake water & {$[141]$} \\
\hline Pymetrozine & Optical & 2.172 & Tap and lake water & {$[142]$} \\
\hline Imidacloprid & Electronical & 106.1 & River water & {$[143]$} \\
\hline Pyrethroid & Biooptical & 6.568 & River water & {$[144]$} \\
\hline Paraquat & Electronical & 0.8 & River water & {$[145]$} \\
\hline Clopyralid & Electrochemical & 0.154 & River water & {$[146]$} \\
\hline Carbendazim & Electronical & 37.473 & River water & {$[147]$} \\
\hline
\end{tabular}


TABLE 1: Continued.

\begin{tabular}{|c|c|c|c|c|}
\hline Analytes & Sensor types & LOD (ng/ml) & Waterbodies & Ref. \\
\hline Quinalphos & Electrochemical & 0.378 & Tap and lake water & [148] \\
\hline Methyl parathion & Biooptical & 1.87 & River water & [149] \\
\hline $2,4-\mathrm{D}$ & Optical & 0.0045 & Tap, bottle, and lake water & {$[150]$} \\
\hline Diethofencarb & Electronical & 320 & River water & [151] \\
\hline Diazinon & Bioelectrochemical & 57.827 & River water & [152] \\
\hline Naptalam & Electrochemical & 4.37 & River water & [153] \\
\hline Phosmet & Biooptical & 0.0004 & Lake water & [154] \\
\hline Phoxim & Che-optical & 298.298 & River water & [155] \\
\hline Bentazone & Electrochemical & 8.918 & Lake and ground water & [156] \\
\hline Fenitrothion & Electronical & 0.155 & Well water & [157] \\
\hline Chlorpyrifos & Bioelectrochemical & 0.07 & Lake water & [158] \\
\hline Lindane & Ele-optical & 0.585 & River and tap water & [159] \\
\hline Difenzoquat & Electrochemical & 102.225 & River and deionized water & [160] \\
\hline Diquat & Electrochemical & 37.844 & River and drinking water & [161] \\
\hline Methyl parathion & Optical & 27.674 & Pond water & [162] \\
\hline $\begin{array}{l}\text { Glyphosate } \\
\text { Aminomethylphosphonic acid }\end{array}$ & Optical & $\begin{array}{l}5.07 \\
1.666\end{array}$ & Lake water & [48] \\
\hline $\begin{array}{l}\text { Atrazine } \\
\text { Chlorpyrifos } \\
\text { Lindane } \\
\text { Tetradifon } \\
\text { Imidacloprid }\end{array}$ & Opt-electrochemical & $\begin{array}{c}25.882 \\
10.167 \\
40.716 \\
14.242 \\
3.322\end{array}$ & River water & [163] \\
\hline Glyphosate & Optical & 845 & River water & {$[49]$} \\
\hline Methyl parathion & Electrochemical & 0.012 & River water & [164] \\
\hline Amitrole & Electrochemical & 58.856 & River water & [165] \\
\hline $\begin{array}{l}\text { Paraoxon } \\
\text { Malathion } \\
\text { Methamidophos } \\
\text { Carbaryl }\end{array}$ & Optical & $\begin{array}{l}0.014 \\
0.033 \\
0.017 \\
0.026\end{array}$ & Tap and river water & [166] \\
\hline Fenitrothion & Electronical & 0.0526 & River water & {$[167]$} \\
\hline Carbendazim & Electrochemical & 5.736 & River water & [168] \\
\hline Ofloxacin & Optical & 0.123 & River and tap water & [169] \\
\hline
\end{tabular}

2.2. Data Analysis. One-way ANOVA (analysis of variation) was conducted to test the differences of LODs among the pesticide groups/heavy metals and among the sensor types. All data were checked for normality before conducting the ANOVA tests and were log-transformed to meet normality and homogeneity assumptions [37]. One case $\left(1.84 \times 10^{-7}\right)$ was deleted from the pesticide sensor dataset due to the outlier when conducting the ANOVA. If significant effects present in the ANOVA, then Tukey's multiple comparison was used for post hoc analysis of significant differences among sensor types or analyte groups [38]. All statistical analyses were carried out using SPSS 24.0.

\section{Results and Discussion}

\subsection{Pesticide Sensors}

3.1.1. Pesticides in Freshwaters. Pesticides are usually classified into three major categories: herbicides, insecticides, and fungicides/bactericides. The application of pesticides is used to con- trol weeds, pest outbreaks, and fungal infestations for the security of global food supply $[15,39,40]$. The worldwide pesticide expenditures increased from $\$ 48.8$ billion in 2008 to $\$ 55.9$ billion in 2012 [41]. After application, these pesticides can enter freshwaters via numerous ways such as wastewater effluent and surface runoff [15]. In a national (US) monitoring network for pesticides in streams and rivers during 1992-2011, the concentrations of one or more pesticides exceeded the aquatic organism benchmark in 61\%-69\%, 45\%, and 53\%$90 \%$ of the streams in agricultural, mixed-land-use, and urban areas, respectively [42]. In Europe, atrazine (herbicide) is among the most frequently detected chemicals in groundwaters [5]. Due to their high frequency of being detected in freshwaters and the toxicity effects on aquatic organisms, pesticides are one of the most common monitored water quality parameters [43-45]. During the last few decades, many sensors have been developed to detect pesticides in freshwaters [46, 47].

Most of the sensor data we collected can be applied in rivers and streams which correspond to the fact that most studies focused on these waterbodies and indicated the needs 
TABLE 2: Criterion maximum concentration and maximum contaminant concentration of some pesticides and heavy metals in freshwaters in the United States.

\begin{tabular}{|c|c|c|}
\hline & CMCs (ng/ml) & MCLs (ng/ml) \\
\hline \multicolumn{3}{|l|}{ Pesticides } \\
\hline Carbaryl & 2.1 & - \\
\hline Chlorpyrifos & 0.083 & - \\
\hline Diazinon & 0.17 & - \\
\hline Parathion & 0.065 & - \\
\hline Dieldrin & 0.24 & - \\
\hline Lindane & 0.95 & 0.2 \\
\hline Atrazine & - & 3 \\
\hline $2,4-\mathrm{D}$ & - & 70 \\
\hline Diquat & - & 20 \\
\hline \multicolumn{3}{|l|}{ Heavy metals } \\
\hline Arsenic & $340(1.0)$ & 10 \\
\hline Cadmium & $1.8(1.14)$ & 5 \\
\hline Chromium $^{3+}$ & $570(0.316)$ & 50 \\
\hline Chromium $^{6+}$ & $16(0.982)$ & 50 \\
\hline Copper & - $(0.96)$ & 130 \\
\hline Lead & $82(1.46)$ & 15 \\
\hline Mercury & $1.4(0.85)$ & 2 \\
\hline Nickel & $470(0.998)$ & - \\
\hline Silver & $3.2(0.85)$ & 100 \\
\hline Zinc & $120(0.978)$ & 500 \\
\hline
\end{tabular}

Note: CMC: criterion maximum concentration for the recommended aquatic life in the United States. Numbers in parentheses of CMCs for heavy metals are conversion factors for dissolved metals. MCL: maximum contaminant limit concentration for drinking water in the United States.

to monitoring pesticides in streams and rivers. The most frequently detected pesticides are paraquat, followed by atrazine and carbaryl (Table 1). This result is in accordance with the most common pesticide contamination in freshwaters [5]. However, only three studies detected glyphosate [48-50], the most widely used herbicide worldwide $[51,52]$. Therefore, more studies should target on the development of glyphosate sensors to get a clearer understanding of the glyphosate contamination in freshwaters. Although the production of herbicides is the highest worldwide [53], more studies focus on insecticide sensors than herbicide sensors (Table 1), probably because organophosphorus pesticides, the most frequently detected analytes, are highly toxic to organisms [54]. Therefore, priority was given to those with relatively high toxicity rather than those used in large quantity when monitoring water quality.

3.1.2. Sensitivity of Pesticide Sensors. The average LOD of pesticide sensors included in this review was $72.53 \pm$ $12.69 \mathrm{ng} / \mathrm{ml}(n=180$, mean $\pm \mathrm{SE})$. Not all of sensors for the detection of pesticides in freshwaters were sensitive enough for ecological and monitoring requirements. The proposed maximum contaminant level, i.e., the maximum permissible level (MCL) of a contaminant in water that is delivered to any user of a public waterbody, for many pesticides (e.g., atrazine and aldicarb) is at the level of $\mathrm{ng} / \mathrm{ml}$ or even less than $1 \mathrm{ng} / \mathrm{ml}$ [170]. For example, the criterion maximum concentrations (CMC) of carbaryl, chlorpyrifos, diazinon, and parathion for aquatic life in freshwaters of the United States are 2.1, 0.083, 0.17, and $0.065 \mathrm{ng} / \mathrm{ml}$, respectively (Table 2). Moreover, more than 5\% of the MCLs for the top 29 commonly regulated pesticides in drinking water exceed the computed upper thresholds for human health risk uncertainty [171], which means that the MCLs for pesticides in drinking water should be stricter and higher sensitive sensors are needed. However, our results indicated that the LODs for $32.8 \%$ of the sensors are higher than $10 \mathrm{ng} / \mathrm{ml}$, and $<50 \%$ of the sensors can reach the level of $3 \mathrm{ng} / \mathrm{ml}$. Therefore, many sensors may not be sensitive enough for the detection of pesticides in freshwaters regarding the requirements for the protection of aquatic life and human health. In addition, there are more than 1,000 pesticides used worldwide to ensure food security. Nevertheless, this review paper only included 97 kinds of pesticides/active ingredients which cover less than $10 \%$ of all pesticides. Therefore, future studies should focus on the largely ignored pesticides because many pesticides have toxic effects on aquatic organisms [172] and human health $[173,174]$. For example, many sensors were developed to analyze organophosphorus pesticides (e.g., chlorpyrifos and carbaryl) while fewer sensors were targeted on organochlorine pesticides such as dichlorodiphenyltrichloroethane (DDT). DDT was widely used for the control of pest and fungus in the last century. Even though DDT has been banned for decades in many countries, it can still be found in $8-100 \%$ of the sampled small streams in three South American countries [175]. Therefore, DDT is still a global concern due to the toxicity, not easy to be degraded, and the tendency to be accumulated in organisms [176]. The LOD of one biooptical sensor used for the detection of DDT in river water can be as low as $0.015 \mathrm{ng} / \mathrm{ml}$ [177].

LODs in this study showed thousands of orders for different analytes and sensors. Among all the sensors been checked, the most sensitive sensor was developed by Kumar et al. [131], in which the indirect detection of malathion through an enzyme-based fluorometric method was applied. This system can achieve an ultrasensitive LOD which is as low as $1.84 \times 10^{-7} \mathrm{ng} / \mathrm{ml}$ and can be spiked for lake water and agricultural runoff water [131]. By contrast, some sensors are relatively "insensitive" with the LODs at the level of $100 \mathrm{ng} / \mathrm{ml}[50,122,141]$. Although, the average LOD for herbicide sensors is higher than that of insecticides and fungicides, there is no significant difference among the three categories of pesticides $\left(F_{2,176}=2.717, P=0.069\right.$, Figure 1). The sensitivity of sensors collected in this paper is similar to that of previous review papers $[34,178]$. Only 22 cases $(12.22 \%)$ were related to fungicide sensors. This extremely low percentage indicated the urgency to improve the monitoring of fungicides in freshwaters, because fungicides are widely occurring in freshwaters and are highly toxic to numerous aquatic organisms $[15,179]$. For the sensor types, we found a similar pattern (Table 1) as some previous review papers that electrochemical [180], optical [33, 35], and biological [181] sensors are among the most widely used sensors for the detection of pesticides in freshwaters. Regarding the sensitivity of different types of sensors, biosensors showed 


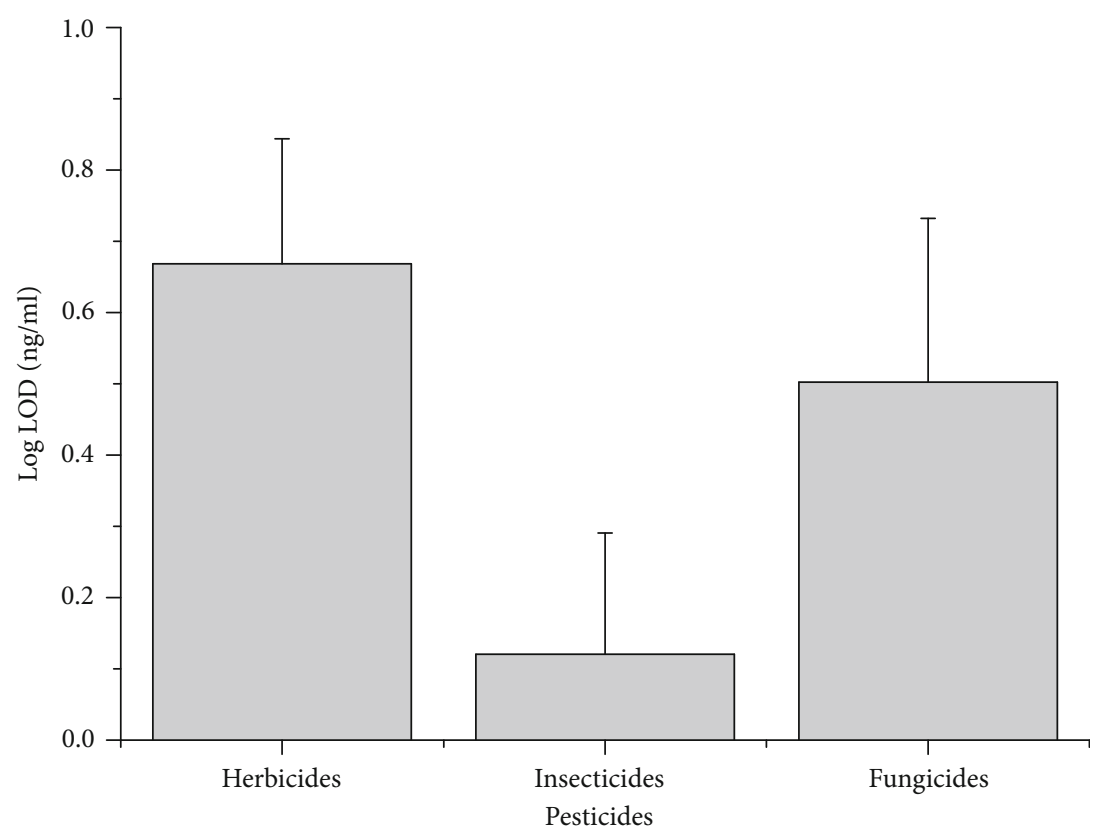

Figure 1: Averages of limit of detection of sensors for herbicides, insecticides, and fungicides. Values are the mean \pm SE.

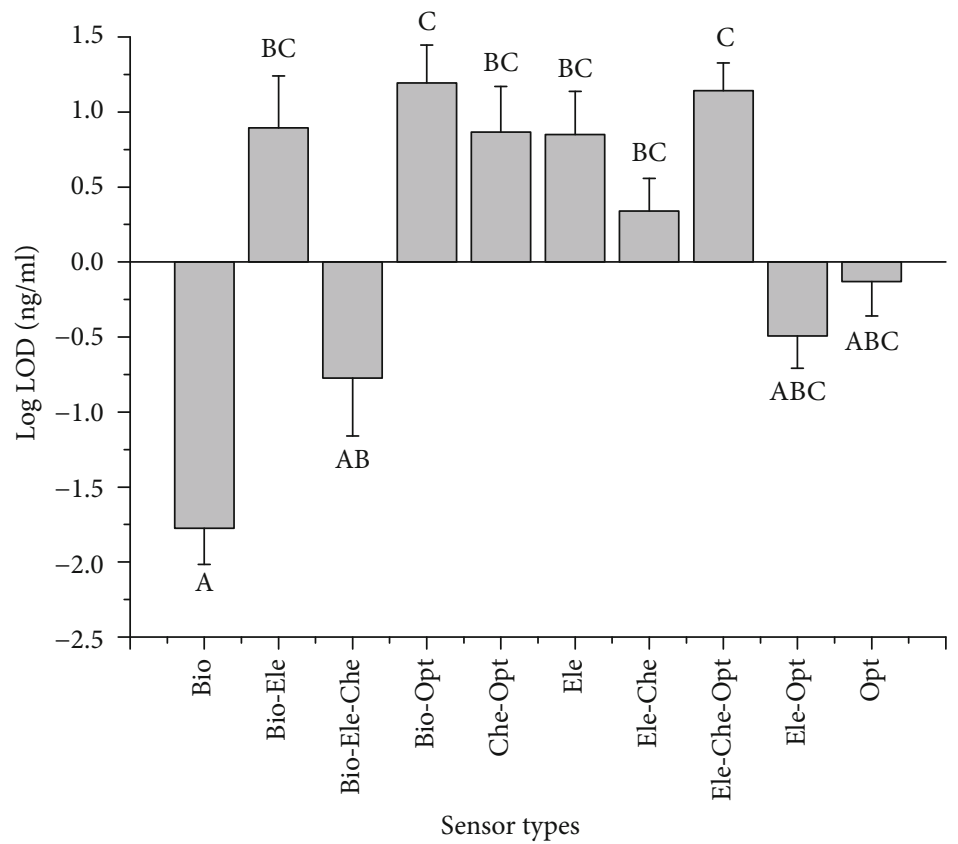

Figure 2: Averages of limit of detection of pesticide sensors based on different detection methods. Values are the mean \pm SE. Different uppercase letters above each bar indicate significant differences after one-way ANOVA and post hoc Tukey (parameters with the same letter are not significantly different between sensors).

the highest sensitivity compared with other sensors, while the biooptical and electrochemical optical sensors indicated the lowest sensitivity $\left(F_{9,169}=7.239, P<0.001\right.$, Figure 2$)$. Biosensors have been widely used in the environmental monitoring [5], given the advantages of biosensors in detecting pesticides and other pollutants over conventional methods: high stability (e.g., they can operate at high temperature), inexpensiveness, possibility for real-time monitoring, high selectivity, and disposability, just to name some of them
[181-183]. Biosensors could be a promising direction for pesticide detection in freshwaters. For example, diatoms, which were popular for the assessment of water quality [184], may be a suitable tool for biosensors.

\subsection{Heavy Metal Sensors}

3.2.1. Heavy Metals in Freshwaters. Heavy metals refer to metallic elements that have a high atomic weight and with a 
TABLE 3: Summary of sensors used to detect heavy metals in freshwaters during the year 2017-2019.

\begin{tabular}{|c|c|c|c|c|}
\hline Analytes & Sensors & LOD (ng/ml) & Waterbodies & Ref. \\
\hline $\mathrm{As}^{3+}$ & Biosensor & 0.005 & Tap, lake, and pond water & [203] \\
\hline $\mathrm{As}^{3+}$ & Electrochemical & 75 & River water & [204] \\
\hline $\begin{array}{l}\mathrm{Cd}^{2+} \\
\mathrm{Pb}^{2+}\end{array}$ & Electrochemical & $\begin{array}{l}0.068 \\
0.105\end{array}$ & Tap and lake water & [205] \\
\hline $\mathrm{Pb}^{2+}$ & Electrochemical & 0.15 & Tap and lake water & {$[206]$} \\
\hline $\begin{array}{l}\mathrm{Pb}^{2+} \\
\mathrm{Hg}^{2+}\end{array}$ & Optical & $\begin{array}{l}0.029 \\
0.044\end{array}$ & River water & [207] \\
\hline $\mathrm{Cu}^{2+}$ & Electrochemical & 9.532 & Tap and river water & [208] \\
\hline $\begin{array}{l}\mathrm{Fe}^{3+} \\
\mathrm{Ni}^{2+}\end{array}$ & & $\begin{array}{l}200 \\
300\end{array}$ & & \\
\hline $\mathrm{Cr}^{6+}$ & Optical & 100 & Tap and lake water & [209] \\
\hline $\mathrm{Cu}^{2+}$ & Optical & 30 & 1 ap and lake water & \\
\hline $\mathrm{Al}^{3+}$ & & $\begin{array}{l}80 \\
40\end{array}$ & & \\
\hline $\mathrm{Zn}^{2+}$ & & & & \\
\hline $\mathrm{Cd}^{2+}$ & Electrochemical & 0.337 & River water & [210] \\
\hline $\mathrm{Pb}^{2+}$ & & 0.2 & & \\
\hline $\mathrm{Cu}^{2+}$ & Electrochemical & 0.2 & Lake water & [211] \\
\hline $\mathrm{Hg}^{2+}$ & & 0.2 & & \\
\hline $\begin{array}{l}\mathrm{Pb}^{2+} \\
\mathrm{Cu}^{2+}\end{array}$ & Electrochemical & $\begin{array}{l}0.6 \\
0.3\end{array}$ & River water & [212] \\
\hline $\mathrm{Ag}^{+}$ & Biosensor & 0.006 & Tap, drinking, pond, and soil water & {$[213]$} \\
\hline $\mathrm{Cd}^{2+}$ & & 0.0056 & & \\
\hline $\mathrm{Pb}^{2+}$ & Electrochemical & 0.0166 & River water & [214] \\
\hline $\mathrm{Cu}^{2+}$ & & 0.001 & & {$[214]$} \\
\hline $\mathrm{Hg}^{2+}$ & & 0.010 & & \\
\hline $\mathrm{As}^{3+}$ & Electrochemical biosensor & 0.000003 & Lake and well water & [215] \\
\hline $\mathrm{Cd}^{2+}$ & Electrochemical & 0.17 & Lake water & [216] \\
\hline $\mathrm{Hg}^{2+}$ & Optical & 0.6 & Tap water & {$[217]$} \\
\hline $\begin{array}{l}\mathrm{Pb}^{2+} \\
\mathrm{Cd}^{2+}\end{array}$ & Electrochemical & $\begin{array}{l}0.17 \\
0.21\end{array}$ & River, lake, and wastewater & [218] \\
\hline $\mathrm{Hg}^{2+}$ & Electrochemical & 6.018 & River water & {$[219]$} \\
\hline $\mathrm{Cu}^{2+}$ & & 0.02 & & \\
\hline $\mathrm{Pb}^{2+}$ & Electronical & 0.03 & River, tap, and well water & [220] \\
\hline $\mathrm{Cr}^{3+}$ & & 0.15 & & \\
\hline $\mathrm{Ag}^{+}$ & Electrochemical & 0.098 & Pond, tap, drinking, and soil water & [221] \\
\hline $\mathrm{Hg}^{2+}$ & Biofluorescent & 0.261 & River water & [222] \\
\hline $\mathrm{Cd}^{2+}$ & Electrochemical & 0.05 & Tap, pond, and river water & [223] \\
\hline $\mathrm{Ni}^{2+}$ & Electrochemical & 0.12 & Tap and river water & [224] \\
\hline $\mathrm{Cu}^{2+}$ & & 3 & & \\
\hline $\mathrm{Cd}^{2+}$ & Electrochemical & 4 & River water & [225] \\
\hline $\mathrm{Pb}^{2+}$ & & 2.5 & & \\
\hline $\mathrm{Cd}^{2+}$ & & 1.012 & & \\
\hline $\mathrm{Pb}^{2+}$ & Flectrochemical & 0.207 & River water & {$[226]$} \\
\hline $\mathrm{Cu}^{2+}$ & Electrocnemical & 0.508 & Kiver Water & \\
\hline $\mathrm{Hg}^{2+}$ & & 0.181 & & \\
\hline $\mathrm{Ni}^{2+}$ & & 240 & & \\
\hline $\mathrm{Cr}^{6+}$ & Electrochemical & 180 & Lake water & [227] \\
\hline $\mathrm{Hg}^{2+}$ & & 190 & & \\
\hline $\mathrm{Pb}^{2+}$ & Electrochemical & 0.5 & River water & [228] \\
\hline
\end{tabular}


TABle 3: Continued.

\begin{tabular}{|c|c|c|c|c|}
\hline Analytes & Sensors & $\mathrm{LOD}(\mathrm{ng} / \mathrm{ml})$ & Waterbodies & Ref. \\
\hline $\mathrm{Hg}^{2+}$ & Optical & 0.261 & Tap and river water & {$[229]$} \\
\hline $\mathrm{As}^{3+}$ & Biooptical & 0.005 & Groundwater & {$[203]$} \\
\hline $\mathrm{Hg}^{2+}$ & Biooptical & 0.241 & Lake and deionized water & {$[230]$} \\
\hline $\mathrm{Pb}^{2+}$ & Bioelectrochemical & 0.000001 & River water & {$[231]$} \\
\hline $\mathrm{Cd}^{2+}$ & Electrochemical & 3.372 & Lake water & {$[232]$} \\
\hline $\begin{array}{l}\mathrm{Hg}^{2+} \\
\mathrm{Cu}^{2+}\end{array}$ & Optical & $\begin{array}{l}7.422 \\
6.672\end{array}$ & River water & {$[233]$} \\
\hline $\begin{array}{l}\mathrm{Pb}^{2+} \\
\mathrm{Cu}^{2+} \\
\mathrm{Hg}^{2+}\end{array}$ & Electrochemical & $\begin{array}{l}0.15 \\
0.07 \\
0.13\end{array}$ & Lake and river water & {$[234]$} \\
\hline $\begin{array}{l}\mathrm{Pb} \\
\mathrm{Cd}\end{array}$ & Electrochemical & $\begin{array}{l}1.68 \\
1.24\end{array}$ & Tap and lake water & {$[235]$} \\
\hline $\begin{array}{l}\mathrm{Cu} 2+ \\
\mathrm{Fe} 3+\end{array}$ & Optical & $\begin{array}{l}0.0064 \\
0.056\end{array}$ & River water & {$[236]$} \\
\hline $\begin{array}{l}\mathrm{Pb}^{2+} \\
\mathrm{Hg}^{2+}\end{array}$ & Biooptical & $\begin{array}{l}1.036 \\
3.731\end{array}$ & Lake water & {$[237]$} \\
\hline $\mathrm{Cd}^{2+}$ & Electrochemical & $\begin{array}{c}1.16 \\
0.152\end{array}$ & $\begin{array}{c}\text { Lake water } \\
\text { Deionized water }\end{array}$ & {$[238]$} \\
\hline $\mathrm{Pb}^{2+}$ & Optical & 0.216 & River and tap water & {$[239]$} \\
\hline $\mathrm{Pb}^{2+}$ & Optical & 0.011 & River water & {$[240]$} \\
\hline $\begin{array}{l}\mathrm{As}^{3+} \\
\mathrm{Cd}^{2+}\end{array}$ & Bioelectronical & $\begin{array}{l}2.248 \\
7.869\end{array}$ & River, tap, and wastewater & {$[241]$} \\
\hline $\begin{array}{l}\mathrm{Cd}^{2+} \\
\mathrm{Pb}^{2+} \\
\mathrm{Cu}^{2+}\end{array}$ & Electrochemical & $\begin{array}{c}0.5 \\
1 \\
5\end{array}$ & River water & {$[242]$} \\
\hline $\mathrm{Cr}^{3+}$ & Biosensor & 0.35 & River and tap water & {$[243]$} \\
\hline $\mathrm{Pb}^{2+}$ & Electrochemical & 4.144 & Lake and mining effluent water & {$[244]$} \\
\hline $\begin{array}{l}\mathrm{Cd}^{2+} \\
\mathrm{Pb}^{2+}\end{array}$ & Electrochemical & $\begin{array}{l}7.45 \\
1.17\end{array}$ & Lake and tap water & {$[245]$} \\
\hline $\begin{array}{l}\mathrm{Zn}^{2+} \\
\mathrm{Cd}^{2+} \\
\mathrm{Pb}^{2+}\end{array}$ & Electrochemical & $\begin{array}{l}0.327 \\
0.225 \\
0.166\end{array}$ & Tap and river water & {$[246]$} \\
\hline $\mathrm{Cu}^{2+}$ & Electrochemical & 25.418 & River, tap, and dam water & {$[247]$} \\
\hline $\begin{array}{l}\mathrm{Cd}^{2+} \\
\mathrm{Pb}^{2+} \\
\mathrm{Ni}^{2+}\end{array}$ & Electrochemical & $\begin{array}{l}0.0025 \\
0.0518 \\
0.0002\end{array}$ & & {$[248]$} \\
\hline $\begin{array}{l}\mathrm{Zn}^{2+} \\
\mathrm{Pb}^{2+} \\
\mathrm{Cu}^{2+}\end{array}$ & Electrochemical & $\begin{array}{l}0.05 \\
0.02 \\
0.03\end{array}$ & Lake water & {$[249]$} \\
\hline $\mathrm{Pb}^{2+}$ & Electrochemical & 2.486 & Tap, lake, and river water & {$[250]$} \\
\hline $\mathrm{Ag}^{+}$ & Bioelectrochemical & 0.00000005 & Tap and lake water & {$[251]$} \\
\hline $\begin{array}{l}\mathrm{Cd}^{2+} \\
\mathrm{Pb}^{2+}\end{array}$ & Electrochemical & $\begin{array}{l}0.2 \\
0.3\end{array}$ & River water & {$[252]$} \\
\hline $\begin{array}{l}\mathrm{Pb}^{2+} \\
\mathrm{Hg}^{2+}\end{array}$ & Bioelectronical & $\begin{array}{l}3.937 \\
3.611\end{array}$ & River water & {$[253]$} \\
\hline $\mathrm{Cu}^{2+}$ & Electrochemical & 19.064 & Tap and river water & {$[254]$} \\
\hline $\begin{array}{l}\mathrm{Pb}^{2+} \\
\mathrm{Cr}^{3+} \\
\mathrm{Hg}^{2+}\end{array}$ & Optical & $\begin{array}{c}192.696 \\
48.356 \\
186.549\end{array}$ & Lake water & {$[255]$} \\
\hline
\end{tabular}


TABLE 3: Continued.

\begin{tabular}{lccc}
\hline Analytes & Sensors & LOD $(\mathrm{ng} / \mathrm{ml})$ & Waterbodies \\
\hline $\mathrm{Cd}^{2+}$ & & 0.001 & Ref. \\
$\mathrm{Cu}^{2+}$ & Chemical & 0.006 & Wastewater \\
$\mathrm{Hg}^{2+}$ & & 0.020 & \\
$\mathrm{~Pb}^{2+}$ & & 0.021 & [256] \\
$\mathrm{Mn}^{2+}$ & Optical & 16 & River water \\
$\mathrm{Fe}^{2+}$ & & 11 & \\
$\mathrm{Cu}^{2+}$ & & 12 & River and tap water \\
$\mathrm{Fe}^{3+}$ & Optical & 50 & \\
$\mathrm{Hg}^{2+}$ & & 0.233 & Lake water \\
$\mathrm{Hg}^{2+}$ & Biooptical & 0.509 & \\
$\mathrm{Hg}^{2+}$ & & 0.602 & [257] \\
$\mathrm{Ag}^{+}$ & & 0.324 & [258] \\
$\mathrm{Cd}^{2+}$ & & 0.152 & [259] \\
$\mathrm{Pb}^{2+}$ & Optical-electronical & 0.029 & [260] \\
$\mathrm{Cd}^{2+}$ & & 0.315 & River and tap water \\
$\mathrm{Pb}^{2+}$ & & 0.292 & Pond wand tap water \\
$\mathrm{As}^{3+}$ & & 0.172 & [261] \\
$\mathrm{Hg}^{2+}$ & 0.321 &
\end{tabular}

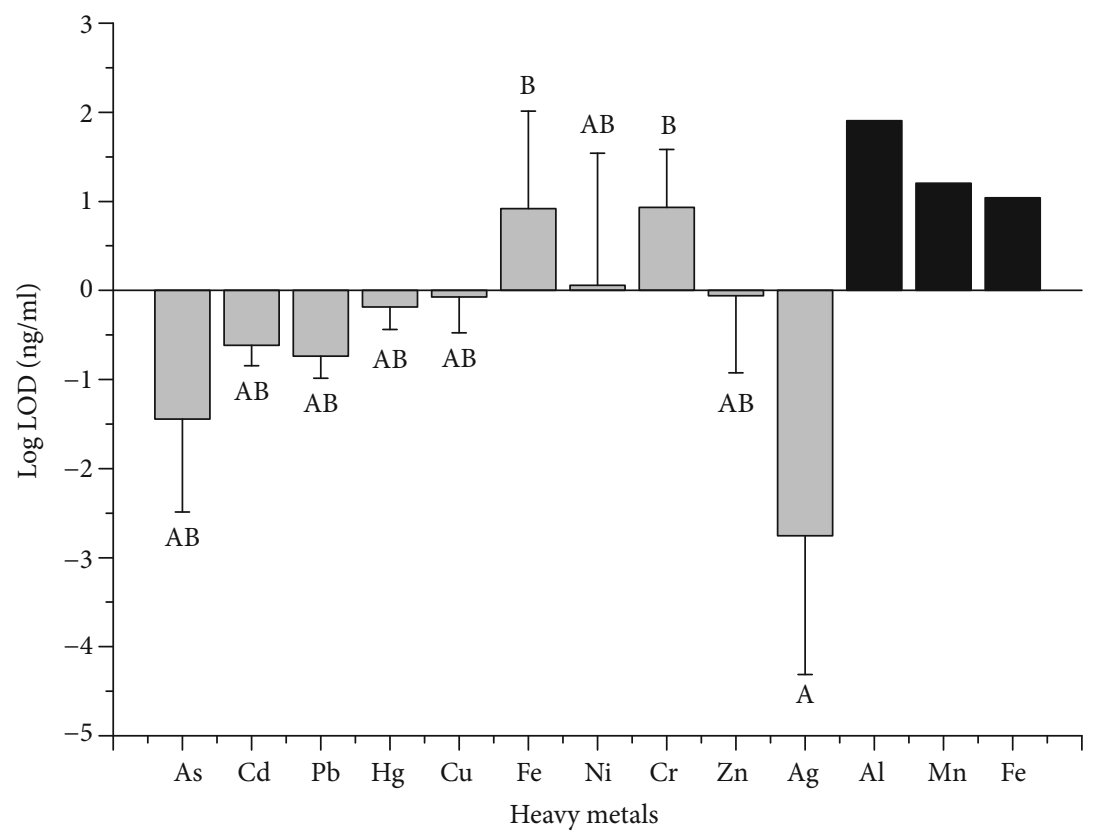

FIgURe 3: Averages of limit of detection of sensors for the detection of heavy metals in freshwaters. Values are the mean \pm SE. Different uppercase letters above each bar indicate significant differences after one-way ANOVA and post hoc Tukey (parameters with the same letter are not significantly different between heavy metal sensors). Only one sensor was included in this review for the detection of Al, Mn, and Fe. Therefore, these three heavy metal sensors were excluded from the ANOVA. The data of $\mathrm{Cr}^{3+}$ and $\mathrm{Cr}^{6+}$ were combined for the ANOVA.

density of at least five times greater than that of water [185]. Aquatic ecosystems can be polluted by heavy metals through multiple ways such as mining, weathering of soils and rocks, industrial wastewater, and surface runoff [186-188]. Natural concentrations of $\mathrm{Pb}$ and $\mathrm{Cd}$ are less than $0.003 \mathrm{ng} / \mathrm{ml}$ in streams [189]. However, heavy metal concentrations may be two or three orders of the natural concentrations or even higher in polluted waterbodies [190,191]. The most common heavy metal pollutants found in aquatic ecosystems are As, $\mathrm{Cd}, \mathrm{Cr}, \mathrm{Cu}, \mathrm{Ni}, \mathrm{Pb}, \mathrm{Hg}$, and $\mathrm{Zn} \mathrm{[192].} \mathrm{For} \mathrm{instance,} \mathrm{Cu}, \mathrm{Fe}$, 


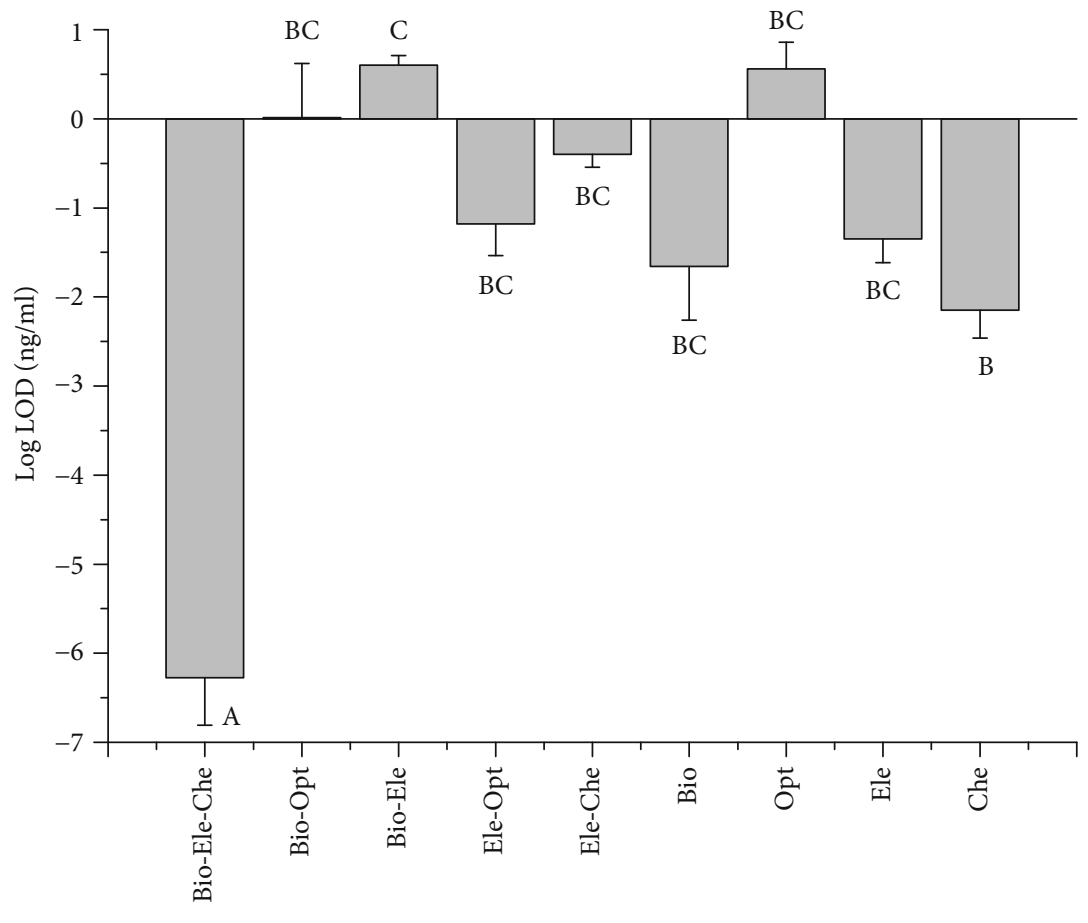

Sensor types

Figure 4: Averages of limit of detection of heavy metal sensors based on different methods. Values are the mean \pm SE. Different uppercase letters above each bar indicate significant differences after one-way ANOVA and post hoc Tukey (parameters with the same letter are not significantly different between sensors).

$\mathrm{Zn}, \mathrm{Mn}$, and Cr were the top five heavy metals of concern in freshwaters in Bohai Region, China, while $\mathrm{Hg}$ showed the lowest risk [193]. The concentrations of many heavy metals in the river Ganga water and sediment exceeded the acceptable concentrations and threatened human health and aquatic organisms [194]. Three countries, i.e., the United States, Germany, and Russia, consume 3/4 of the world's most widely used metals. Human health and aquatic ecosystems can be threatened by heavy metals especially by $\mathrm{Pb}, \mathrm{Cd}, \mathrm{Hg}$, and As $[195,196]$. For example, groundwaters contaminated by As threatened millions of people's drinking water safety in developing countries such as India, Cambodia, and Vietnam [4]. Aquatic organisms still suffer from the toxic effects of heavy metals even though upstream mining activities ceased for decades [197]. Due to the high toxicity and them commonly found in freshwaters [198, 199], heavy metals are among the most important indices when monitoring water quality $[45,200]$.

3.2.2. Sensitivity of Heavy Metal Sensors. Altogether, 61 publications were selected during the years 2017-2019 (the data were updated until October 2019), with nine types of sensors used for the detection of 13 heavy metals in freshwaters (Table 3). The average LOD for all sensors is $65.36 \pm$ $47.51 \mathrm{ng} / \mathrm{ml}(n=117$, mean $\pm \mathrm{SE})$. The sensitivity of sensors differed among the detected heavy metals $\left(F_{9,104}=2.289\right.$, $P=0.022$, Figure 3). Sensors targeted on Ag had the highest sensitivity while the sensors used to detect $\mathrm{Fe}$ and $\mathrm{Cr}$ showed the lowest sensitivity. The sensitivity of many sensors can satisfy the requirements for drinking water and wild life protection. The LODs of some sensors were still higher than CMCs or MCLs. Especially for mercury sensors, 30\% of the collected sensors failed to satisfy the CMC or MCL requirements. It reminds us that higher sensitivity sensors should be developed to protect human health and aquatic organisms. In addition, the CMC/MCL may be changed due to the national regulation [201,202] which means that the higher sensitivity sensors may be needed to detect lower concentrations of heavy metals. As mentioned above, As, $\mathrm{Cr}, \mathrm{Ni}$, and $\mathrm{Zn}$ are among the highest concentrations of heavy metals in freshwaters [192]. However, limited sensors were developed to detect these heavy metals. Therefore, more diverse sensors should be developed to analyze these heavy metals.

Regarding the sensor types, more than half of the heavy metal sensors were based on electrochemical methods, while few studies applied biological ways (Table 3). The sensitivity of sensors for heavy metal detection varied among sensor types $\left(F_{8,108}=12.5, P<0.001\right.$, Figure 4$)$. Bioelectrochemical sensors had the highest sensitivity, while bioelectronical sensors showed the lowest sensitivity. The most sensitive sensor was a bioelectrochemical sensor which was developed by Zhang et al. [251] for the detection of silver in tap and lake water, and the LOD was as low as $5.0 \times 10^{-8} \mathrm{ng} / \mathrm{ml}$. On the contrary, a pigment-based whole-cell biosensor developed for the analysis of copper in pond and tap water showed the highest LOD $(5547.6 \mathrm{ng} / \mathrm{ml})$ [262]. The average LOD of heavy metals based on electrochemical methods was $12.187 \pm 5.446 \mathrm{ng} / \mathrm{ml} \quad(n=65$, mean $\pm \mathrm{SE})$. The LOD of 
electrochemical sensors in this review is higher than the LODs of electrochemical sensors in previous review papers $[210,263,264]$. This probably is because the LODs of four electrochemical sensors were higher than $50 \mathrm{ng} / \mathrm{ml}$ which increased the average LOD. Electrochemical sensors have the advantages such as easy to manipulate, cheap, suitable for field monitoring, and portable which make it suitable for heavy metal detection [263]. However, the optical sensors in this review did not show higher sensitivity than electrochemical sensors as mentioned in a previous study [263]. This is caused by two studies which used colorimetric and luminescent detection; the LODs in these two studies are $30-300 \mathrm{ng} / \mathrm{ml}[209,255]$.

\section{Conclusion}

This review presents the general information on sensors for the detection of pesticides and heavy metals in freshwaters. The studied sensors covered less than $10 \%$ of all registered pesticides/ingredients. Most of the selected pesticide sensors were used to analyze insecticides and herbicides while limited studies were focused on fungicides. The LODs of $\sim 30 \%$ of the pesticide sensors failed to meet the maximum permissible concentrations for aquatic life and drinking water. Biosensors showed the highest sensitivity and appeared to be a promising technology in future development for the detection of pesticides in freshwaters. The average LOD of sensors for the detection of heavy metals is $65.36 \mathrm{ng} / \mathrm{ml}$ during the last three years. The LODs of a small fraction of sensors such as mercury sensors were higher than the upper threshold concentrations for the protection of wild life and drinking water safety. Most of the heavy metal sensors were designed to detect mercury, cadmium, lead, and copper based on electrochemical methods. These results imply us that higher sensitivity sensors should be developed in the future. In addition, future sensors should cover more pesticides and heavy metals (e.g., glyphosate and zinc) which are commonly detected in waterbodies and are highly toxic to aquatic organisms and human health.

\section{Conflicts of Interest}

The authors declare that there is no conflict of interest regarding the publication of this paper.

\section{Acknowledgments}

This work was supported by the National Natural Science Foundation of China (grant numbers 41501566 and 41601576), Fundamental Research Funds for the Central Universities (grant number 2412018JC002), Program of Introducing Talents of Discipline to Universities (grant number B16011), Foundation of Education Department of Jilin Province (grant number 2014 B050), and Basal Research Fund for Undergraduate Universities of Heilongjiang Province of China (grant number 2019-KYYWF-0598).

\section{References}

[1] J. Mateo-Sagasta, S. M. Zadeh, H. Turral, and J. Burke, Water Pollution from Agriculture: A Global Review, the Food and Agriculture Organization of the United Nations; the Water Land and Ecosystems research program, Rome, Italy; Colombo, Sri Lanka, 2017.

[2] K. Li, Z. Zhang, H. Yang et al., "Effects of instream restoration measures on the physical habitats and benthic macroinvertebrates in an agricultural headwater stream," Ecological Engineering, vol. 122, pp. 252-262, 2018.

[3] T. Mani, S. Primpke, C. Lorenz, G. Gerdts, and P. BurkhardtHolm, "Microplastic pollution in benthic midstream sediments of the Rhine River," Environmental Science \& Technology, vol. 53, no. 10, pp. 6053-6062, 2019.

[4] R. P. Schwarzenbach, T. Egli, T. B. Hofstetter, U. von Gunten, and B. Wehrli, "Global water pollution and human health," Annual Review of Environment and Resources, vol. 35, no. 1, pp. 109-136, 2010.

[5] M. Gavrilescu, K. Demnerová, J. Aamand, S. Agathos, and F. Fava, "Emerging pollutants in the environment: present and future challenges in biomonitoring, ecological risks and bioremediation," New Biotechnology, vol. 32, no. 1, pp. 147156, 2015.

[6] UNEP, A Snapshot of the World's Water Quality: Towards a Global Assessment, Nairobi, United Nations Environment Programme, 2016.

[7] EPA, Water Quality Assessment and TMDL Information, United States Environmental Protection Agency, 2015.

[8] D. Hou, G. Li, and P. Nathanail, "An emerging market for groundwater remediation in China: policies, statistics, and future outlook," Frontiers of Environmental Science \& Engineering, vol. 12, no. 1, p. 16, 2018.

[9] B. Grizzetti, D. Lanzanova, C. Liquete, A. Reynaud, and A. C. Cardoso, "Assessing water ecosystem services for water resource management," Environmental Science \& Policy, vol. 61, pp. 194-203, 2016.

[10] J. Turunen, J. Markkula, M. Rajakallio, and J. Aroviita, "Riparian forests mitigate harmful ecological effects of agricultural diffuse pollution in medium-sized streams," Science of the Total Environment, vol. 649, pp. 495-503, 2019.

[11] H. M. Valett and D. T. Ely, "Acidification, stress, and detrital processing: implications for ecosystem function in headwater streams," Hydrobiologia, vol. 826, no. 1, pp. 233-246, 2019.

[12] K. Li, C. He, J. Zhuang et al., "Long-term changes in the water quality and macroinvertebrate communities of a subtropical river in South China," Water, vol. 7, no. 12, pp. 63-80, 2015.

[13] Z. Zhang, H. Yang, H. Yang, Y. Li, and T. Wang, "The impact of roadside ditches on juvenile and sub-adult Bufo melanostictus migration," Ecological Engineering, vol. 36, no. 10, pp. 1242-1250, 2010.

[14] P. A. Green, C. J. Vörösmarty, I. Harrison, T. Farrell, L. Sáenz, and B. M. Fekete, "Freshwater ecosystem services supporting humans: pivoting from water crisis to water solutions," Global Environmental Change, vol. 34, pp. 108-118, 2015.

[15] J. P. Zubrod, M. Bundschuh, G. Arts et al., "Fungicides: an overlooked pesticide class?," Environmental Science \& Technology, vol. 53, no. 7, pp. 3347-3365, 2019.

[16] K. Sekabira, H. O. Origa, T. A. Basamba, G. Mutumba, and E. Kakudidi, "Assessment of heavy metal pollution in the urban stream sediments and its tributaries," International 
Journal of Environmental Science \& Technology, vol. 7, no. 3, pp. 435-446, 2010.

[17] G. Woodward, M. O. Gessner, P. S. Giller et al., "Continentalscale effects of nutrient pollution on stream ecosystem functioning," Science, vol. 336, no. 6087, pp. 1438-1440, 2012.

[18] WWAP, The United Nations World Water Development Report 2017: Wastewater, the Untapped Resource, In Place de Fontenoy Paris, France, 2017.

[19] C. Yu, X. Huang, H. Chen et al., "Managing nitrogen to restore water quality in China," Nature, vol. 567, no. 7749, pp. 516-520, 2019.

[20] M. Le Moal, C. Gascuel-Odoux, A. Ménesguen et al., "Eutrophication: a new wine in an old bottle?," Science of the Total Environment, vol. 651, pp. 1-11, 2019.

[21] V. H. Smith, "Eutrophication of freshwater and coastal marine ecosystems a global problem," Environmental Science and Pollution Research, vol. 10, no. 2, pp. 126-139, 2003.

[22] Z. Zhang, L. Cao, Z. Zhu et al., "Evaluation on soil bioengineering measures in agricultural areas: poorer durability of wooden structures and better aboveground habitat improvements," Ecological Engineering, vol. 129, pp. 1-10, 2019.

[23] L. L. Osborne and D. A. Kovacic, "Riparian vegetated buffer strips in water-quality restoration and stream management," Freshwater Biology, vol. 29, no. 2, pp. 243-258, 1993.

[24] J. S. Bash and C. M. Ryan, "Stream restoration and enhancement projects: is anyone monitoring?," Environmental Management, vol. 29, no. 6, pp. 877-885, 2002.

[25] S. C. Mukhopadhyay and A. Mason, Smart Sensors for RealTime Water Quality Monitoring, Springer, 2013.

[26] M. V. Storey, B. van der Gaag, and B. P. Burns, "Advances in on-line drinking water quality monitoring and early warning systems," Water Research, vol. 45, no. 2, pp. 741-747, 2011.

[27] J. Bartram and R. Ballance, Water Quality Monitoring: A Practical Guide to the Design and Implementation of Freshwater Quality Studies and Monitoring Programmes, CRC Press, 1996.

[28] P. Kruse, "Review on water quality sensors," Journal of Physics D: Applied Physics, vol. 51, no. 20, p. 25, 2018.

[29] L. Parra, G. Lloret, J. Lloret, and M. Rodilla, "Physical sensors for precision aquaculture: a review," IEEE Sensors Journal, vol. 18, no. 10, pp. 3915-3923, 2018.

[30] M. Farré, L. Kantiani, S. Pérez, D. Barceló, and D. Barceló, "Sensors and biosensors in support of EU Directives," TrAC Trends in Analytical Chemistry, vol. 28, no. 2, pp. 170-185, 2009.

[31] N. A. Cloete, R. Malekian, and L. Nair, "Design of smart sensors for real-time water quality monitoring," IEEE Access, vol. 4, pp. 3975-3990, 2016.

[32] N. de Acha, C. Elosúa, J. M. Corres, and F. J. Arregui, "Fluorescent sensors for the detection of heavy metal ions in aqueous media," Sensors, vol. 19, no. 3, p. 599, 2019.

[33] E. J. Llorent-Martínez, P. Ortega-Barrales, M. L. Fernándezde Córdova, and A. Ruiz-Medina, "Trends in flow-based analytical methods applied to pesticide detection: a review," Analytica Chimica Acta, vol. 684, no. 1-2, pp. 30-39, 2011.

[34] G. A. Ibañez and G. M. Escandar, "Luminescence sensors applied to water analysis of organic pollutants-an update," Sensors, vol. 11, no. 12, pp. 11081-11102, 2011.

[35] S. A. Nsibande and P. B. C. Forbes, "Fluorescence detection of pesticides using quantum dot materials - a review," Analytica Chimica Acta, vol. 945, pp. 9-22, 2016.
[36] A. Gahlaut, A. Gothwal, A. K. Chhillar, and V. Hooda, "Electrochemical biosensors for determination of organophosphorus compounds: review," Open Journal of Applied Biosensor, vol. 1, no. 1, pp. 1-8, 2012.

[37] Z. Yuan and H. Y. H. Chen, "Global trends in senesced-leaf nitrogen and phosphorus," Global Ecology and Biogeography, vol. 18, no. 5, pp. 532-542, 2009.

[38] J. Liu, C. Feng, D. Wang, L. Wang, B. J. Wilsey, and Z. Zhong, "Impacts of grazing by different large herbivores in grassland depend on plant species diversity," Journal of Applied Ecology, vol. 52, no. 4, pp. 1053-1062, 2015.

[39] B. Rashid, T. Husnain, and S. Riazuddin, "Herbicides and pesticides as potential pollutants: a global problem," in Plant Adaptation and Phytoremediation, M. Ashraf, M. Ozturk, and M. S. A. Ahmad, Eds., pp. 427-447, Springer Netherlands, Dordrecht, 2010.

[40] W. Zhang, "Global pesticide use: profile, trend, cost/benefit and more," Proceedings of the International Academy of Ecology and Environmental Sciences, vol. 8, no. 1, pp. 1-27, 2018.

[41] D. Atwood and C. Paisley-Jones, Pesticides Industry Sales and Usage: 2008-2012 Market Estimates, US Environmental Protection Agency, Washington, DC, USA, 2017.

[42] W. W. Stone, R. J. Gilliom, and K. R. Ryberg, "Pesticides in U.S. streams and rivers: occurrence and trends during 1992-2011," Environmental Science \& Technology, vol. 48, no. 19, pp. 11025-11030, 2014.

[43] P. Palma, M. Kuster, P. Alvarenga et al., "Risk assessment of representative and priority pesticides, in surface water of the Alqueva reservoir (south of Portugal) using on-line solid phase extraction-liquid chromatography-tandem mass spectrometry," Environment International, vol. 35, no. 3, pp. 545-551, 2009.

[44] J. Robles-Molina, B. Gilbert-López, J. F. García-Reyes, and A. Molina-Díaz, "Monitoring of selected priority and emerging contaminants in the Guadalquivir River and other related surface waters in the province of Jaen, South East Spain," Science of the Total Environment, vol. 479-480, pp. 247-257, 2014.

[45] S. Zgheib, R. Moilleron, and G. Chebbo, "Priority pollutants in urban stormwater: part 1 - case of separate storm sewers," Water Research, vol. 46, no. 20, pp. 6683-6692, 2012.

[46] P. Joshi, A. Bisht, T. Tyagi, S. Mehtab, and M. Zaidi, "Electrochemical sensor for the detection of pesticides in environmental sample: a review," IJCS, vol. 6, no. 2, pp. 3199-3205, 2018.

[47] C. Steffens, J. Steffens, A. Marcia Graboski, A. Manzoli, and F. Lima Leite, "16- nanosensors for detection of pesticides in water," in New Pesticides and Soil Sensors, A. M. Grumezescu, Ed., pp. 595-635, Academic Press, 2017.

[48] E. A. O. Pereira, V. F. Melo, G. Abate, and J. C. Masini, "Determination of glyphosate and aminomethylphosphonic acid by sequential-injection reversed-phase chromatography: method improvements and application in adsorption studies," Analytical and Bioanalytical Chemistry, vol. 411, no. 11, pp. 2317-2326, 2019.

[49] L. B. Jennings, S. Shuvaev, M. A. Fox, R. Pal, and D. Parker, "Selective signalling of glyphosate in water using europium luminescence," Dalton Transactions, vol. 47, no. 45, pp. 16145-16154, 2018.

[50] H. Kwon, K. M. Chan, and E. T. Kool, "DNA as an environmental sensor: detection and identification of pesticide 
contaminants in water with fluorescent nucleobases," Organic \& Biomolecular Chemistry, vol. 15, no. 8, pp. 18011809, 2017.

[51] R. Annett, H. R. Habibi, and A. Hontela, "Impact of glyphosate and glyphosate-based herbicides on the freshwater environment," Journal of Applied Toxicology, vol. 34, no. 5, pp. 458-479, 2014.

[52] N. M. van Straalen and J. Legler, "Decision-making in a storm of discontent," Science, vol. 360, no. 6392, pp. 958-960, 2018.

[53] W. Zhang, F. Jiang, and J. Ou, "Global pesticide consumption and pollution: with China as a focus," Proceedings of the International Academy of Ecology and Environmental Sciences, vol. 1, no. 2, pp. 125-144, 2011.

[54] S. Y. Wee and A. Z. Aris, "Ecological risk estimation of organophosphorus pesticides in riverine ecosystems," Chemosphere, vol. 188, pp. 575-581, 2017.

[55] L. Tang, G.-M. Zeng, G.-L. Shen, Y.-P. Li, Y. Zhang, and D.L. Huang, "Rapid detection of picloram in agricultural field samples using a disposable immunomembrane-based electrochemical sensor," Environmental Science \& Technology, vol. 42, no. 4, pp. 1207-1212, 2008.

[56] H. G. Zuo, J. X. Zhu, C. R. Zhan et al., "Preparation of malathion MIP-SPE and its application in environmental analysis," Environmental Monitoring and Assessment, vol. 187, no. 7, p. 394, 2015.

[57] Z.-L. Shen, D. Yuan, Q.-D. Su et al., "Selective solid-phase extraction using molecularly imprinted polymer for analysis of methamidophos in water and soil samples," Bioscience, Biotechnology, and Biochemistry, vol. 75, no. 3, pp. 473-479, 2011.

[58] X. Zhu, J. Yang, Q. Su, J. Cai, and Y. Gao, "Selective solidphase extraction using molecularly imprinted polymer for the analysis of polar organophosphorus pesticides in water and soil samples," Journal of Chromatography A, vol. 1092, no. 2, pp. 161-169, 2005.

[59] R. P. Cerejeira, C. Delerue-Matos, and C. M. Vaz, "Development of an FIA system with amperometric detection for determination of bentazone in estuarine waters," Analytical and Bioanalytical Chemistry, vol. 373, no. 4-5, pp. 295-298, 2002.

[60] R. Solná, S. Sapelnikova, P. Skládal et al., "Multienzyme electrochemical array sensor for determination of phenols and pesticides," Talanta, vol. 65, no. 2, pp. 349-357, 2005.

[61] M. G. F. Sales, M. C. V. F. Vaz, C. Delerue-Matos, S. A. A. Almeida, M. F. Barroso, and H. A. O. Ferreira, "Flow amperometric determination of carbofuran and fenobucarb," International Journal of Environmental Analytical Chemistry, vol. 88, no. 1, pp. 37-49, 2008.

[62] C. La Rosa, F. Pariente, L. Hernández, and E. Lorenzo, "Amperometric flow-through biosensor for the determination of pesticides," Analytica Chimica Acta, vol. 308, no. 13, pp. 129-136, 1995.

[63] G. Istamboulie, R. Durbiano, D. Fournier, J.-L. Marty, and T. Noguer, "Biosensor-controlled degradation of chlorpyrifos and chlorfenvinfos using a phosphotriesterase-based detoxification column," Chemosphere, vol. 78, no. 1, pp. 1-6, 2010.

[64] L. Švorc, M. Rievaj, and D. Bustin, "Green electrochemical sensor for environmental monitoring of pesticides: determination of atrazine in river waters using a boron-doped diamond electrode," Sensors and Actuators B: Chemical, vol. 181, pp. 294-300, 2013.
[65] L. B. O. dos Santos, M. S. P. Silva, and J. C. Masini, "Developing a sequential injection-square wave voltammetry (SI-SWV) method for determination of atrazine using a hanging mercury drop electrode," Analytica Chimica Acta, vol. 528, no. 1, pp. 21-27, 2005.

[66] L. B. O. dos Santos, G. Abate, and J. C. Masini, "Determination of atrazine using square wave voltammetry with the hanging mercury drop electrode (HMDE)," Talanta, vol. 62, no. 4, pp. 667-674, 2004.

[67] C. M. P. Vaz, S. Crestana, S. A. S. Machado, L. H. Mazo, and L. A. Avaca, "Electroanalytical determination of the herbicide atrazine in natural waters," International Journal of Environmental Analytical Chemistry, vol. 62, no. 1, pp. 65-76, 1996.

[68] D. De Souza, R. A. de Toledo, A. Galli et al., "Determination of triazine herbicides: development of an electroanalytical method utilizing a solid amalgam electrode that minimizes toxic waste residues, and a comparative study between voltammetric and chromatographic techniques," Analytical and Bioanalytical Chemistry, vol. 387, no. 6, pp. 2245-2253, 2007.

[69] L. C. S. Figueiredo-Filho, D. C. Azzi, B. C. Janegitz, and O. Fatibello-Filho, "Determination of atrazine in natural water samples by differential pulse adsorptive stripping voltammetry using a bismuth film electrode," Electroanalysis, vol. 24, no. 2, pp. 303-308, 2012.

[70] G. Jeanty, A. Wojciechowska, J.-L. Marty, and M. Trojanowicz, "Flow-injection amperometric determination of pesticides on the basis of their inhibition of immobilized acetylcholinesterases of different origin," Analytical and Bioanalytical Chemistry, vol. 373, no. 8, pp. 691-695, 2002.

[71] A. H. Kamel, F. T. C. Moreira, S. A. A. Almeida, and M. G. F. Sales, "Novel potentiometric sensors of molecular imprinted polymers for specific binding of chlormequat," Electroanalysis, vol. 20, no. 2, pp. 194-202, 2008.

[72] S. Suwansa-ard, P. Kanatharana, P. Asawatreratanakul, C. Limsakul, B. Wongkittisuksa, and P. Thavarungkul, "Semi disposable reactor biosensors for detecting carbamate pesticides in water," Biosensors and Bioelectronics, vol. 21, no. 3, pp. 445-454, 2005.

[73] P. Mulchandani, W. Chen, and A. Mulchandani, "Flow injection amperometric enzyme biosensor for direct determination of organophosphate nerve agents," Environmental Science \& Technology, vol. 35, no. 12, pp. 2562-2565, 2001.

[74] B. Bucur, M. Dondoi, A. Danet, and J.-L. Marty, "Insecticide identification using a flow injection analysis system with biosensors based on various cholinesterases," Analytica Chimica Acta, vol. 539, no. 1-2, pp. 195-201, 2005.

[75] M. Á. González-Martínez, Á. Maquieira, and R. Puchades, "Analysis of atrazine in water and vegetables using immunosensors working in organic media," International Journal of Environmental Analytical Chemistry, vol. 83, no. 7-8, pp. 633-642, 2003.

[76] P. Pulido-Tofiño, J. M. Barrero-Moreno, and M. C. PérezConde, "Flow-through fluoroimmunosensor for isoproturon determination in agricultural foodstuff: evaluation of antibody immobilization on solid support," Analytica Chimica Acta, vol. 417, no. 1, pp. 85-94, 2000.

[77] M. A. González-Martínez, S. Morais, R. Puchades, A. Maquieira, A. Abad, and A. Montoya, "Development of an automated controlled-pore glass flow-through 
immunosensor for carbaryl," Analytica Chimica Acta, vol. 347, no. 1-2, pp. 199-205, 1997.

[78] E. J. Llorent-Martínez, J. F. García-Reyes, P. Ortega-Barrales, and A. Molina-Díaz, "Flow-through fluorescencebased optosensor with on-line solid-phase separation for the simultaneous determination of a ternary pesticide mixture," Journal of AOAC International, vol. 88, no. 3, pp. 860-865, 2005.

[79] I. Sánchez-Barragán, K. Karim, J. M. Costa-Fernández, S. A. Piletsky, and A. Sanz-Medel, "A molecularly imprinted polymer for carbaryl determination in water," Sensors and Actuators B: Chemical, vol. 123, no. 2, pp. 798-804, 2007.

[80] J. F. García Reyes, E. J. Llorent Martínez, P. Ortega Barrales, and A. Molina Díaz, "Multiwavelength fluorescence based optosensor for simultaneous determination of fuberidazole, carbaryl and benomyl," Talanta, vol. 64, no. 3, pp. 742-749, 2004.

[81] E. J. Llorent-Martínez, P. Ortega-Barrales, and A. MolinaDíaz, "Multi-commutated flow-through multi-optosensing: a tool for environmental analysis," Spectroscopy Letters, vol. 39, no. 6, pp. 619-629, 2006.

[82] G. N. Piccirilli, G. M. Escandar, F. C. Cañada, I. D. Merás, and A. M. de la Peña, "Flow-through photochemically induced fluorescence optosensor for the determination of linuron," Talanta, vol. 77, no. 2, pp. 852-857, 2008.

[83] J. López Flores, M. L. Fernández de Córdova, and A. Molina Díaz, "Flow-through optosensing device implemented with photochemically-induced fluorescence for the rapid and simple screening of metsulfuron methyl in environmental waters," Journal of Environmental Monitoring, vol. 11, no. 5, pp. 1080-1085, 2009.

[84] A. Domínguez-Vidal, P. Ortega-Barrales, and A. MolinaDíaz, "Environmental water samples analysis of pesticides by means of chemometrics combined with fluorimetric multioptosensing," Journal of Fluorescence, vol. 17, no. 3, pp. 271-277, 2007.

[85] S. Herranz, J. Ramón-Azcón, E. Benito-Peña, M. D. Marazuela, M. P. Marco, and M. C. Moreno-Bondi, "Preparation of antibodies and development of a sensitive immunoassay with fluorescence detection for triazine herbicides," Analytical and Bioanalytical Chemistry, vol. 391, no. 5, pp. 18011812, 2008.

[86] G. N. Piccirilli and G. M. Escandar, "A novel flow-through fluorescence optosensor for the determination of thiabendazole," Analytica Chimica Acta, vol. 601, no. 2, pp. 196-203, 2007.

[87] R. Badía and M. E. Díaz-García, "Cyclodextrin-based optosensor for the determination of warfarin in waters," Journal of Agricultural and Food Chemistry, vol. 47, no. 10, pp. 4256-4260, 1999.

[88] J. L. Flores, M. L. Fernández De Córdova, and A. Molina Díaz, "Simultaneous flow-injection solid-phase fluorometric determination of thiabendazole and metsulfuron methyl using photochemical derivatization," Analytical Sciences, vol. 25, no. 5, pp. 681-686, 2009.

[89] A. Salinas-Castillo, J. F. Fernández-Sánchez, A. SeguraCarretero, and A. Fernández-Gutiérrez, "A facile flowthrough phosphorimetric sensing device for simultaneous determination of naptalam and its metabolite 1-naphthylamine," Analytica Chimica Acta, vol. 522, no. 1, pp. 1924, 2004.
[90] G. N. Piccirilli and G. M. Escandar, "Flow injection analysis with on-line nylon powder extraction for room- temperature phosphorescence determination of thiabendazole," Analytica Chimica Acta, vol. 646, no. 1-2, pp. 90-96, 2009.

[91] E. Mauriz, A. Calle, A. Abad et al., "Determination of carbaryl in natural water samples by a surface plasmon resonance flow-through immunosensor," Biosensors and Bioelectronics, vol. 21, no. 11, pp. 2129-2136, 2006.

[92] J. L. Guzmán Mar, L. López Martínez, P. L. López de Alba, J. E. Castrejón Durán, and V. Cerdà Martín, "Optical fiber reflectance sensor coupled to a multisyringe flow injection system for preconcentration and determination of 1naphthylamine in water samples," Analytica Chimica Acta, vol. 573-574, pp. 406-412, 2006.

[93] M. Agudo, A. Ríos, and M. Valcárcel, "Automatic continuous-flow determination of paraquat at the subnanogram per millilitre level," Analytica Chimica Acta, vol. 281, no. 1, pp. 103-109, 1993.

[94] Q.-Q. Bian, Y.-F. Liu, and J.-S. Yu, "CdTe/CdS semiconductor quantum dots as a highly sensitive sensor for pesticide paraquat," Chemical Journal of Chinese Universities, vol. 6, 2010.

[95] G. M. Durán, A. M. Contento, and Á. Ríos, "Use of Cdse/ZnS quantum dots for sensitive detection and quantification of paraquat in water samples," Analytica Chimica Acta, vol. 801, pp. 84-90, 2013.

[96] F. Maya, J. M. Estela, and V. Cerdà, "Improved spectrophotometric determination of paraquat in drinking waters exploiting a multisyringe liquid core waveguide system," Talanta, vol. 85, no. 1, pp. 588-595, 2011.

[97] N. Mai, X. Liu, W. Wei, S. Luo, and W. Liu, "Electrochemical determination of paraquat using a DNA-modified carbon ionic liquid electrode," Microchimica Acta, vol. 174, no. 1-2, pp. 89-95, 2011.

[98] Y. Li, G. Yao, C. Ma, M. Gong, C. Yu, and N. Jie, "Determination of paraquat in water, rice, and urine samples by resonance light scattering technique with DNA," Analytical Letters, vol. 44, no. 4, pp. 709-716, 2011.

[99] L. C. S. de Figueiredo-Filho, V. B. dos Santos, B. C. Janegitz et al., "Differential pulse voltammetric determination of paraquat using a bismuth-film electrode," Electroanalysis, vol. 22, no. 11, pp. 1260-1266, 2010.

[100] L. B. O. dos Santos, C. M. C. Infante, and J. C. Masini, "Development of a sequential injection-square wave voltammetry method for determination of paraquat in water samples employing the hanging mercury drop electrode," Analytical and Bioanalytical Chemistry, vol. 396, no. 5, pp. 1897-1903, 2010.

[101] C. M. C. Infante, A. Morales-Rubio, M. de la Guardia, and F. R. P. Rocha, "A multicommuted flow system with solenoid micro-pumps for paraquat determination in natural waters," Talanta, vol. 75, no. 5, pp. 1376-1381, 2008.

[102] M. Takino, S. Daishima, and K. Yamaguchi, "Determination of diquat and paraquat in water by liquid chromatography/clectrospray-mass spectrometry using volatile ion-pairing reagents," Analytical Sciences, vol. 16, no. 7, pp. 707-711, 2000.

[103] V. Y. Taguchi, S. W. D. Jenkins, P. W. Crozier, and D. T. Wang, "Determination of diquat and paraquat in water by liquid chromatography-(electrospray ionization) mass spectrometry," Journal of the American Society for Mass Spectrometry, vol. 9, no. 8, pp. 830-839, 1998. 
[104] J. C. Marr and J. B. King, "A simple high performance liquid chromatography/ionspray tandem mass spectrometry method for the direct determination of paraquat and diquat in water," Rapid Communications in Mass Spectrometry, vol. 11, no. 5, pp. 479-483, 1997.

[105] Y. Fan, L. Liu, D. Sun et al., "'Turn-off" fluorescent data array sensor based on double quantum dots coupled with chemometrics for highly sensitive and selective detection of multicomponent pesticides," Analytica Chimica Acta, vol. 916, pp. 84-91, 2016.

[106] X. Wu, Y. Song, X. Yan et al., "Carbon quantum dots as fluorescence resonance energy transfer sensors for organophosphate pesticides determination," Biosensors and Bioelectronics, vol. 94, pp. 292-297, 2017.

[107] M. Amjadi and R. Jalili, "Molecularly imprinted mesoporous silica embedded with carbon dots and semiconductor quantum dots as a ratiometric fluorescent sensor for diniconazole," Biosensors and Bioelectronics, vol. 96, pp. 121-126, 2017.

[108] N. Shams, H. N. Lim, R. Hajian et al., "A promising electrochemical sensor based on $\mathrm{Au}$ nanoparticles decorated reduced graphene oxide for selective detection of herbicide diuron in natural waters," Journal of Applied Electrochemistry, vol. 46, no. 6, pp. 655-666, 2016.

[109] M. S. Kim, G. W. Kim, and T. J. Park, "A facile and sensitive detection of organophosphorus chemicals by rapid aggregation of gold nanoparticles using organic compounds," Biosensors and Bioelectronics, vol. 67, pp. 408-412, 2015.

[110] F. Arduini, S. Cinti, V. Caratelli, L. Amendola, G. Palleschi, and D. Moscone, "Origami multiple paper-based electrochemical biosensors for pesticide detection," Biosensors and Bioelectronics, vol. 126, pp. 346-354, 2019.

[111] M. Khadem, F. Faridbod, P. Norouzi et al., "Modification of carbon paste electrode based on molecularly imprinted polymer for electrochemical determination of diazinon in biological and environmental samples," Electroanalysis, vol. 29, no. 3, pp. 708-715, 2017.

[112] R. Šelešovská, L. Janíková, and J. Chýlková, “Green electrochemical sensors based on boron-doped diamond and silver amalgam for sensitive voltammetric determination of herbicide metamitron," Monatshefte für Chemie-Chemical Monthly, vol. 146, no. 5, pp. 795-805, 2015.

[113] X. Wang, T. Hou, S. Dong, X. Liu, and F. Li, "Fluorescence biosensing strategy based on mercury ion-mediated DNA conformational switch and nicking enzyme-assisted cycling amplification for highly sensitive detection of carbamate pesticide," Biosensors and Bioelectronics, vol. 77, pp. 644-649, 2016.

[114] A. Wong, M. V. Foguel, S. Khan, F. M. . Oliveira, C. R. T. Tarley, and M. D. P. T. Sotomayor, "Development of an electrochemical sensor modified with MWCNT-COOH and MIP for detection of diuron," Electrochimica Acta, vol. 182, pp. 122-130, 2015.

[115] P. B. Deroco, B. C. Lourencao, and O. Fatibello-Filho, "The use of modified electrode with carbon black as sensor to the electrochemical studies and voltammetric determination of pesticide mesotrione," Microchemical Journal, vol. 133, pp. 188-194, 2017.

[116] T. Nasir, G. Herzog, M. Hébrant, C. Despas, L. Liu, and A. Walcarius, "Mesoporous silica thin films for improved electrochemical detection of paraquat," ACS Sensors, vol. 3, no. 2, pp. 484-493, 2018.
[117] M. Brycht, S. Skrzypek, J. Robak et al., "Ultra trace level determination of fenoxanil by highly sensitive square wave adsorptive stripping voltammetry in real samples with a renewable silver amalgam film electrode," Journal of Electroanalytical Chemistry, vol. 738, pp. 69-76, 2015.

[118] B. Kaur, R. Srivastava, and B. Satpati, "Nanocrystalline titanosilicate-acetylcholinesterase electrochemical biosensor for the ultra-trace detection of toxic organophosphate pesticides," ChemElectroChem, vol. 2, no. 8, pp. 1164-1173, 2015.

[119] M. Khadem, F. Faridbod, P. Norouzi, A. R. Foroushani, M. R. Ganjali, and S. J. Shahtaheri, "Biomimetic electrochemical sensor based on molecularly imprinted polymer for dicloran pesticide determination in biological and environmental samples," Journal of the Iranian Chemical Society, vol. 13, no. 11, pp. 2077-2084, 2016.

[120] N. Shams, H. N. Lim, R. Hajian et al., "Electrochemical sensor based on gold nanoparticles/ethylenediamine-reduced graphene oxide for trace determination of fenitrothion in water," RSC Advances, vol. 6, no. 92, pp. 89430-89439, 2016.

[121] Q. J. Luo, Y. X. Li, M. Q. Zhang, P. Qiu, and Y. H. Deng, “A highly sensitive, dual-signal assay based on rhodamine B covered silver nanoparticles for carbamate pesticides," Chinese Chemical Letters, vol. 28, no. 2, pp. 345-349, 2017.

[122] E. Caballero-Díaz, S. Benítez-Martínez, and M. Valcárcel, "Rapid and simple nanosensor by combination of graphene quantum dots and enzymatic inhibition mechanisms," Sensors and Actuators B: Chemical, vol. 240, pp. 90-99, 2017.

[123] N. F. M. Rodrigues, S. Y. Neto, R. D. C. S. Luz, F. S. Damos, and H. Yamanaka, "Ultrasensitive determination of malathion using acetylcholinesterase immobilized on chitosanfunctionalized magnetic iron nanoparticles," Biosensors, vol. 8, no. 1, p. 16, 2018.

[124] D. J. E. Costa, J. C. S. Santos, F. A. C. Sanches-Brandão, W. F. Ribeiro, G. R. Salazar-Banda, and M. C. U. Araujo, "Borondoped diamond electrode acting as a voltammetric sensor for the detection of methomyl pesticide," Journal of Electroanalytical Chemistry, vol. 789, pp. 100-107, 2017.

[125] E. H. Duarte, J. Casarin, E. R. Sartori, and C. R. T. Tarley, "Highly improved simultaneous herbicides determination in water samples by differential pulse voltammetry using boron-doped diamond electrode and solid phase extraction on cross-linked poly(vinylimidazole)," Sensors and Actuators B: Chemical, vol. 255, pp. 166-175, 2018.

[126] H. Li, X. Wei, Y. Xu et al., "A thin shell and "sunny shape" molecular imprinted fluorescence sensor in selective detection of trace level pesticides in river," Journal of Alloys and Compounds, vol. 705, pp. 524-532, 2017.

[127] K. Skrzypczyńska, K. Kuśmierek, and A. Świątkowski, “Carbon paste electrodes modified with various carbonaceous materials for the determination of 2,4-dichlorophenoxyacetic acid by differential pulse voltammetry," Journal of Electroanalytical Chemistry, vol. 766, pp. 8-15, 2016.

[128] E. Demir and R. İnam, "Square wave voltammetric determination of fomesafen herbicide using modified nanostructure carbon paste electrode as a sensor and application to food samples," Food Analytical Methods, vol. 10, no. 1, pp. 7482, 2017.

[129] K. Sipa, M. Brycht, A. Leniart et al., “ $\beta$-Cyclodextrins incorporated multi-walled carbon nanotubes modified electrode for the voltammetric determination of the pesticide dichlorophen," Talanta, vol. 176, pp. 625-634, 2018. 
[130] M. J. U. Toro, L. D. Marestoni, and M. D. P. T. Sotomayor, “A new biomimetic sensor based on molecularly imprinted polymers for highly sensitive and selective determination of hexazinone herbicide," Sensors and Actuators B: Chemical, vol. 208, pp. 299-306, 2015.

[131] D. N. Kumar, S. A. Alex, R. S. S. Kumar, N. Chandrasekaran, and A. Mukherjee, "Acetylcholinesterase inhibition-based ultrasensitive fluorometric detection of malathion using unmodified silver nanoparticles," Colloids and Surfaces A: Physicochemical and Engineering Aspects, vol. 485, pp. 111117, 2015.

[132] J. Nebu, J. S. A. Devi, R. S. Aparna, B. Aswathy, G. M. Lekha, and G. Sony, "Fluorescence turn-on detection of fenitrothion using gold nanoparticle quenched fluorescein and its separation using superparamagnetic iron oxide nanoparticle," Sensors and Actuators B-Chemical, vol. 277, pp. 271-280, 2018.

[133] G. G. Gerent, C. Q. Gonçalves, P. S. da Silva, and A. Spinelli, "_In situ_ bismuth-film electrode for square-wave cathodic voltammetric detection of pendimethalin at nanomolar level," Electrochimica Acta, vol. 168, pp. 379-385, 2015.

[134] B. Kaur, B. Satpati, and R. Srivastava, " $\mathrm{ZrO}_{2}$ supported nanoZSM-5 nanocomposite material for the nanomolar electrochemical detection of metol and bisphenol A," RSC Advances, vol. 6, no. 70, pp. 65736-65746, 2016.

[135] R. Kaur and N. Kaur, "A novel cation ensembled fluorescent organic nanoparticle for selective detection of organophosphorus insecticides," Dyes and Pigments, vol. 139, pp. 310317, 2017.

[136] D. D. Thiare, A. Coly, D. Sarr et al., "Determination of the fenvalerate insecticide in natural waters by a photochemically-induced fluorescence method," Macedonian Journal of Chemistry and Chemical Engineering, vol. 34, no. 2, pp. 245-254, 2015.

[137] A. Ozcan, M. Gurbuz, and A. Ozbal, "Preparation of a double-step modified carbon paste electrode for the voltammetric determination of propham via bulk modification with fumed silica and drop-casting of maghemite-modified fumed silica nanocomposite," Sensors and Actuators B-Chemical, vol. 255, pp. 1517-1524, 2018.

[138] A. Ozcan, M. Gurbuz, and A. A. Ozcan, "Preparation of a disposable and low-cost electrochemical sensor for propham detection based on over-oxidized poly(thiophene) modified pencil graphite electrode," Talanta, vol. 187, pp. 125-132, 2018.

[139] M. B. Gholivand, N. Karimian, and M. Torkashvand, "A graphene-based electrochemical sensor for sensitive determination of cyanazine," Journal of Analytical Chemistry, vol. 70, no. 3, pp. 384-391, 2015.

[140] J. Wang, Y. Wang, H. Qiu et al., “A novel sensitive luminescence probe microspheres for rapid and efficient detection of $\tau$-fluvalinate in Taihu Lake," Scientific Reports, vol. 7, no. $1,2017$.

[141] H. Wu, Y. Luo, C. Hou et al., "Rapid and fingerprinted monitoring of pesticide methyl parathion on the surface of fruits/leaves as well as in surface water enabled by gold nanorods based casting-and-sensing SERS platform," Talanta, vol. 200, pp. 84-90, 2019.

[142] J. Kang, Y. Zhang, X. Li et al., "Rapid and sensitive colorimetric sensing of the insecticide pymetrozine using melaminemodified gold nanoparticles," Analytical Methods, vol. 10, no. 4, pp. 417-421, 2018.
[143] W. D. A. Paiva, T. M. B. F. Oliveira, C. P. Sousa et al., "Electroanalysis of imidacloprid insecticide in river waters using functionalized multi-walled carbon nanotubes modified glassy carbon electrode," Journal of the Electrochemical Society, vol. 165, no. 10, pp. B431-B435, 2018.

[144] H. Li, X. Wang, Z. Wang et al., “A high-performance SERSimprinted sensor doped with silver particles of different surface morphologies for selective detection of pyrethroids in rivers," New Journal of Chemistry, vol. 41, no. 23, pp. 14342-14350, 2017.

[145] R. Faramarzi, A. R. Taheri, and M. Roushani, "Determination of paraquat in fruits and natural water using $\mathrm{Ni}(\mathrm{OH})_{2}$ nanoparticles-carbon nanotubes composite modified carbon ionic liquid electrode," Analytical \& Bioanalytical Electrochemistry, vol. 7, no. 6, pp. 666-683, 2015.

[146] A. Özcan and M. Gürbüz, "Development of a modified electrode by using a nanocomposite containing acid- activated multi-walled carbon nanotube and fumed silica for the voltammetric determination of clopyralid," Sensors and Actuators B: Chemical, vol. 255, pp. 262-267, 2018.

[147] M. Brycht, O. Vajdle, K. Sipa et al., “ $\beta$-Cyclodextrin and multiwalled carbon nanotubes modified boron-doped diamond electrode for voltammetric assay of carbendazim and its corrosion inhibition behavior on stainless steel," Ionics, vol. 24, no. 3, pp. 923-934, 2018.

[148] N. G. Khare, R. A. Dar, and A. K. Srivastava, “Adsorptive stripping voltammetry for trace determination of quinalphos employing silicon carbide nanoparticles modified glassy carbon electrode," Electroanalysis, vol. 27, no. 2, pp. 503-509, 2015.

[149] S. Lan, X. Wang, Q. Liu et al., "Fluorescent sensor for indirect measurement of methyl parathion based on alkaline-induced hydrolysis using N-doped carbon dots," Talanta, vol. 192, pp. 368-373, 2019.

[150] X. Feng, G. Zhang, L. K. Chin, A. Q. Liu, and B. Liedberg, "Highly sensitive, label-free detection of 2,4-dichlorophenoxyacetic acid using an optofluidic chip," ACS Sensors, vol. 2, no. 7, pp. 955-960, 2017.

[151] A. Sinha, Y. Huang, and H. Zhao, "Preparation of 3D assembly of mono layered molybdenum disulfide nanotubules for rapid screening of carbamate pesticide diethofencarb," Talanta, vol. 204, pp. 455-464, 2019.

[152] M. Arvand and M. Dehsaraei, “Amperometric determination of diazinon by gold nanorods/ds-DNA/graphene oxide sandwich-modified electrode," Ionics, vol. 24, no. 8, pp. 2445-2454, 2018.

[153] M. Brycht, A. Leniart, J. Zavašnik et al., "Synthesis and characterization of the thermally reduced graphene oxide in argon atmosphere, and its application to construct graphene paste electrode as a naptalam electrochemical sensor," Analytica Chimica Acta, vol. 1035, pp. 22-31, 2018.

[154] L. Zhou, Y. Cao, B. Lin, S. Song, Y. Yu, and L. Shui, "In-situ visual and ultrasensitive detection of phosmet using a fluorescent immunoassay probe," Sensors and Actuators B: Chemical, vol. 241, pp. 915-922, 2017.

[155] J. Feng, G. Yang, Y. Mei et al., "Macroscopic visual detection of phoxim by calix[4] arene-based host-guest chemistry," Sensors and Actuators B: Chemical, vol. 271, pp. 264-270, 2018.

[156] A. Geto, J. S. Noori, J. Mortensen, W. E. Svendsen, and M. Dimaki, "Electrochemical determination of bentazone using simple screen-printed carbon electrodes," Environment International, vol. 129, pp. 400-407, 2019. 
[157] N. Y. Sreedhar, M. S. Kumar, and K. Krishnaveni, "Enhanced electrocatalytic determination of fenitrothion at graphene and silver-zirconia nanosensor," Monatshefte für Chemie Chemical Monthly, vol. 146, no. 9, pp. 1385-1393, 2015.

[158] W. Cheng, Z. Zheng, J. Yang et al., "The visible light-driven and self-powered photoelectrochemical biosensor for organophosphate pesticides detection based on nitrogen doped carbon quantum dots for the signal amplification," Electrochimica Acta, vol. 296, pp. 627-636, 2019.

[159] K. K. Masibi, O. E. Fayemi, A. S. Adekunle, E. S. M. Sherif, and E. E. Ebenso, "Electrocatalysis of lindane using antimony oxide nanoparticles based-SWCNT/PANI nanocomposites," Frontiers in Chemistry, vol. 6, 2018.

[160] J. Gajdár, J. Barek, and J. Fischer, "Electrochemical microcell based on silver solid amalgam electrode for voltammetric determination of pesticide difenzoquat," Sensors and Actuators B: Chemical, vol. 299, article 126931, 2019.

[161] N. A. Zambianco, T. A. Silva, H. Zanin, O. Fatibello-Filho, and B. C. Janegitz, "Novel electrochemical sensor based on nanodiamonds and manioc starch for detection of diquat in environmental samples," Diamond and Related Materials, vol. 98, article 107512, 2019.

[162] X. Hu, F. Wang, Q. Peng et al., "Construction of a luminescent sensor based on a lanthanide complex for the highly efficient detection of methyl parathion," RSC Advances, vol. 9, no. 23, pp. 13048-13053, 2019.

[163] P. Mandal, D. Sahoo, P. Sarkar, K. Chakraborty, and S. Das, "Fluorescence turn-on and turn-off sensing of pesticides by carbon dot-based sensor," New Journal of Chemistry, vol. 43, no. 30, pp. 12137-12151, 2019.

[164] X. C. Fu, C. Zhang, X. H. Li, J. Zhang, and G. Wei, "Mono-6thio- $\beta$-cyclodextrin-functionalized AuNP/two-dimensional TiO2nanosheet nanocomposite for the electrochemical determination of trace methyl parathion in water," Analytical Methods, vol. 11, no. 37, pp. 4751-4760, 2019.

[165] S. Zhou, H. Xu, Y. Wei et al., "Platelet nitrogen and sulfur codoped ordered mesoporous carbon with inexpensive methylene blue as a single precursor for electrochemical detection of herbicide amitrole," Nano, vol. 14, no. 8, article 1950104, 2019.

[166] J. Korram, L. Dewangan, R. Nagwanshi, I. Karbhal, K. K. Ghosh, and M. L. Satnami, "A carbon quantum dot-gold nanoparticle system as a probe for the inhibition and reactivation of acetylcholinesterase: detection of pesticides," New Journal of Chemistry, vol. 43, no. 18, pp. 6874-6882, 2019.

[167] A. Özcan, D. Topçuoğulları, and A. Atılır Özcan, "Fenitrothion sensing with reduced graphene oxide decorated fumed silica nanocomposite modified glassy carbon electrode," Sensors and Actuators B-Chemical, vol. 284, pp. 179-185, 2019.

[168] J. G. M. Yanke, G. K. Dedzo, and E. Ngameni, "Solvent effect on the grafting of an organophilic silane onto smectite-type clay: application as electrode modifiers for pesticide detection," Electroanalysis, vol. 29, no. 8, pp. 1894-1902, 2017.

[169] H. Yi, Z. Yan, L. Wang et al., "Fluorometric determination for ofloxacin by using an aptamer and SYBR Green I," Microchimica Acta, vol. 186, no. 10, 2019.

[170] L. H. Nowell and E. A. Resek, "National standards and guidelines for pesticides in water, sediment, and aquatic organisms: application to water-quality assessments," in Reviews of Environmental Contamination and Toxicology: Continuation of Residue Reviews, G. W. Ware, Ed., pp. 1-154, Springer New York, New York, NY, USA, 1994.
[171] Z. Li and A. Jennings, "Worldwide regulations of standard values of pesticides for human health risk control: a review," International Journal of Environmental Research and Public Health, vol. 14, no. 7, p. 826, 2017.

[172] L. Pisa, D. Goulson, E.-C. Yang et al., "An update of the Worldwide Integrated Assessment (WIA) on systemic insecticides. Part 2: impacts on organisms and ecosystems," Environmental Science and Pollution Research, 2017.

[173] P. Nicolopoulou-Stamati, S. Maipas, C. Kotampasi, P. Stamatis, and L. Hens, "Chemical pesticides and human health: the urgent need for a new concept in agriculture," Frontiers in Public Health, vol. 4, no. 148, 2016.

[174] K.-H. Kim, E. Kabir, and S. A. Jahan, "Exposure to pesticides and the associated human health effects," Science of the Total Environment, vol. 575, pp. 525-535, 2017.

[175] L. Hunt, C. Bonetto, V. H. Resh et al., "Insecticide concentrations in stream sediments of soy production regions of South America," Science of the Total Environment, vol. 547, pp. 114-124, 2016.

[176] B. B. Prasad and D. Jauhari, "A dual-template biomimetic molecularly imprinted dendrimer-based piezoelectric sensor for ultratrace analysis of organochlorine pesticides," Sensors and Actuators B: Chemical, vol. 207, pp. 542-551, 2015.

[177] E. Mauriz, A. Calle, J. J. Manclús et al., “Optical immunosensor for fast and sensitive detection of DDT and related compounds in river water samples," Biosensors and Bioelectronics, vol. 22, no. 7, pp. 1410-1418, 2007.

[178] P. F. P. Barbosa, E. G. Vieira, L. R. Cumba et al., "Voltammetric techniques for pesticides and herbicides detection-an overview," International Journal of Electrochemical Science, vol. 14, pp. 3418-3433, 2019.

[179] T. A. McMahon, N. T. Halstead, S. Johnson et al., "Fungicideinduced declines of freshwater biodiversity modify ecosystem functions and services," Ecology Letters, vol. 15, no. 7, pp. 714-722, 2012.

[180] R. Ramachandran, V. Mani, S. M. Chen, G. G. Kumar, and M. Govindasamy, "Recent developments in electrode materials and methods for pesticide analysis-an overview," International Journal of Electrochemical Science, vol. 10, no. 1, pp. 859-869, 2015.

[181] S. Boulanouar, S. Mezzache, A. Combès, and V. Pichon, "Molecularly imprinted polymers for the determination of organophosphorus pesticides in complex samples," Talanta, vol. 176, pp. 465-478, 2018.

[182] J. Chouler and M. Di Lorenzo, "Water quality monitoring in developing countries; can microbial fuel cells be the answer?" Biosensors, vol. 5, no. 3, pp. 450-470, 2015.

[183] A. ElMekawy, H. M. Hegab, D. Pant, and C. P. Saint, "Bio-analytical applications of microbial fuel cell-based biosensors for onsite water quality monitoring," Journal of Applied Microbiology, vol. 124, no. 1, pp. 302-313, 2018.

[184] Y. Zhang, J. Tao, J. Wang et al., "Trends in diatom research since 1991 based on topic modeling," Microorganisms, vol. 7, no. 8, p. 213, 2019.

[185] P. B. Tchounwou, C. G. Yedjou, A. K. Patlolla, and D. J. Sutton, "Heavy metal toxicity and the environment," in Molecular, Clinical and Environmental Toxicology: Volume 3: Environmental Toxicology, A. Luch, Ed., pp. 133-164, Springer Basel, Basel, 2012. 
[186] J. O. Duruibe, M. Ogwuegbu, and J. Egwurugwu, "Heavy metal pollution and human biotoxic effects," International Journal of Physical Sciences, vol. 2, no. 5, pp. 112-118, 2007.

[187] Y. Yi, Z. Yang, and S. Zhang, "Ecological risk assessment of heavy metals in sediment and human health risk assessment of heavy metals in fishes in the middle and lower reaches of the Yangtze River basin," Environmental Pollution, vol. 159, no. 10, pp. 2575-2585, 2011.

[188] C. Sun, Z. Zhang, H. Cao, M. Xu, and L. Xu, "Concentrations, speciation, and ecological risk of heavy metals in the sediment of the Songhua River in an urban area with petrochemical industries," Chemosphere, vol. 219, pp. 538-545, 2019.

[189] Y. Erel, J. J. Morgan, and C. C. Patterson, "Natural levels of lead and cadmium in a remote mountain stream," Geochimica et Cosmochimica Acta, vol. 55, no. 3, pp. 707-719, 1991.

[190] A. O’Sullivan, D. Wicke, and T. Cochrane, "Heavy metal contamination in an urban stream fed by contaminated airconditioning and stormwater discharges," Environmental Science and Pollution Research, vol. 19, no. 3, pp. 903-911, 2012.

[191] M. S. Islam, M. K. Ahmed, M. Raknuzzaman, M. HabibullahAl-Mamun, and M. K. Islam, "Heavy metal pollution in surface water and sediment: a preliminary assessment of an urban river in a developing country," Ecological Indicators, vol. 48, pp. 282-291, 2015.

[192] V. Masindi and K. L. Muedi, "Environmental contamination by heavy metals," in Heavy Metals, pp. 115-133, IntechOpen, Aglan, France, 2018.

[193] C. Su, Y. Lu, A. C. Johnson et al., "Which metal represents the greatest risk to freshwater ecosystem in Bohai Region of China?," Ecosystem Health and Sustainability, vol. 3, no. 2, article e01260, 2017.

[194] D. Paul, "Research on heavy metal pollution of river Ganga: a review," Annals of Agrarian Science, vol. 15, no. 2, pp. 278286, 2017.

[195] L. Järup, "Hazards of heavy metal contamination," British Medical Bulletin, vol. 68, no. 1, pp. 167-182, 2003.

[196] M. S. Schuler and R. A. Relyea, "A review of the combined threats of road salts and heavy metals to freshwater systems," Bioscience, vol. 68, no. 5, pp. 327-335, 2018.

[197] H. Lefcort, J. Vancura, and E. L. Lider, "75 years after mining ends stream insect diversity is still affected by heavy metals," Ecotoxicology, vol. 19, no. 8, pp. 1416-1425, 2010.

[198] S. Cheng, "Heavy metal pollution in China: origin, pattern and control," Environmental Science and Pollution Research, vol. 10, no. 3, pp. 192-198, 2003.

[199] I. Razo, L. Carrizales, J. Castro, F. Díaz-Barriga, and M. Monroy, "Arsenic and heavy metal pollution of soil, water and sediments in a semi-arid climate mining area in Mexico," Water, Air, and Soil Pollution, vol. 152, no. 1-4, pp. 129-152, 2004.

[200] G. Teijon, L. Candela, K. Tamoh, A. Molina-Díaz, and A. R. Fernández-Alba, "Occurrence of emerging contaminants, priority substances (2008/105/CE) and heavy metals in treated wastewater and groundwater at Depurbaix facility (Barcelona, Spain)," Science of the Total Environment, vol. 408, no. 17, pp. 3584-3595, 2010.

[201] J. McKay and A. Moeller, "Are mandatory regulations required for water quality in Australia?," Water Policy, vol. 4, no. 2, pp. 95-118, 2002.

[202] F. W. Pontius, "Future directions in water quality regulations," Journal-AWWA, vol. 89, no. 3, pp. 40-54, 1997.
[203] J. Pan, Q. Li, D. Zhou, and J. Chen, "Ultrasensitive aptamer biosensor for arsenic (III) detection based on label- free triple-helix molecular switch and fluorescence sensing platform," Talanta, vol. 189, pp. 370-376, 2018.

[204] M. M. Marei, K. L. Kaht, T. J. Roussel, R. S. Keynton, and R. P. Baldwin, "Measurement of As(III) with in situ subtraction of background and interferent signals by double potential stepanodic stripping coulometry," Sensors and Actuators B: Chemical, vol. 301, article 127005, 2019.

[205] D. Qin, A. Chen, X. Mamat et al., "Double-shelled yolk-shell [email protected] microspheres based electrochemical sensor for determination of cadmium and lead ions," Analytica Chimica Acta, vol. 1078, pp. 32-41, 2019.

[206] X. Hu, H. Guo, T. Qi et al., "Miniaturized electrochemical sensor with micropillar array working electrode for trace lead online measurement in tap water," Journal of Micromechanics and Microengineering, vol. 29, no. 10, article 105005, 2019.

[207] Z. Liu, W. Jin, F. Wang et al., "Ratiometric fluorescent sensing of $\mathrm{Pb}^{2+}$ and $\mathrm{Hg}^{2+}$ with two types of carbon dot nanohybrids synthesized from the same biomass," Sensors and Actuators B: Chemical, vol. 296, p. 126698, 2019.

[208] P. Wei, Z. Zhu, R. Song, Z. Li, and C. Chen, "An ionimprinted sensor based on chitosan-graphene oxide composite polymer modified glassy carbon electrode for environmental sensing application," Electrochimica Acta, vol. 317, pp. 93-101, 2019.

[209] F. Li, Y. Hu, Z. Li, J. Liu, L. Guo, and J. He, “Three-dimensional microfluidic paper-based device for multiplexed colorimetric detection of six metal ions combined with use of a smartphone," Analytical and Bioanalytical Chemistry, vol. 411, no. 24, pp. 6497-6508, 2019.

[210] Y. Chen, D. Zhang, D. Wang, L. Lu, X. Wang, and G. Guo, “A carbon-supported BiSn nanoparticles based novel sensor for sensitive electrochemical determination of Cd (II) ions," Talanta, vol. 202, pp. 27-33, 2019.

[211] N. Q. Giao, V. H. Dang, P. T. H. Yen et al., "Au nanodendrite incorporated graphite pencil lead as a sensitive and simple electrochemical sensor for simultaneous detection of $\mathrm{Pb}(\mathrm{II})$, $\mathrm{Cu}(\mathrm{II})$ and $\mathrm{Hg}(\mathrm{II})$," Journal of Applied Electrochemistry, vol. 49, no. 8, pp. 839-846, 2019.

[212] S. Singh, A. Pankaj, S. Mishra, K. Tewari, and S. Pratap Singh, "Cerium oxide-catalyzed chemical vapor deposition grown carbon nanofibers for electrochemical detection of $\mathrm{Pb}(\mathrm{II})$ and $\mathrm{Cu}(\mathrm{II})$, , Journal of Environmental Chemical Engineering, vol. 7, no. 4, article 103250, 2019.

[213] W. Xiao, Y. Gao, Y. Zhang et al., "Enhanced 3D paper-based devices with a personal glucose meter for highly sensitive and portable biosensing of silver ion," Biosensors and Bioelectronics, vol. 137, pp. 154-160, 2019.

[214] W. Wu, M. Jia, Z. Zhang et al., "Sensitive, selective and simultaneous electrochemical detection of multiple heavy metals in environment and food using a lowcost $\mathrm{Fe}_{3} \mathrm{O}_{4}$ nanoparticles/fluorinated multi-walled carbon nanotubes sensor," Ecotoxicology and Environmental Safety, vol. 175, pp. 243-250, 2019.

[215] R. Yadav, V. Kushwah, M. S. Gaur et al., "Electrochemical aptamer biosensor for $\mathrm{As}^{3+}$ based on apta deep trapped AgAu alloy nanoparticles-impregnated glassy carbon electrode," International Journal of Environmental Analytical Chemistry, pp. 1-12, 2019.

[216] X. Zhao, W. Bai, Y. Yan, Y. Wang, and J. Zhang, "Core-shell self-doped polyaniline coated metal-organic-framework 
(SPAN@UIO-66-NH2) screen printed electrochemical sensor for $\mathrm{Cd}^{2+}$ ions," Journal of the Electrochemical Society, vol. 166, no. 12, pp. B873-B880, 2019.

[217] S. Sajed, K. Vafaei, F. Arefi et al., "Instant sensitive measurement of $\mathrm{Hg}$ concentration using lab-on-a-phone colorimetry," Physica Status Solidi A, vol. 216, no. 14, article 1800871, 2019.

[218] B. Maleki, M. Baghayeri, M. Ghanei-Motlagh et al., "Polyamidoamine dendrimer functionalized iron oxide nanoparticles for simultaneous electrochemical detection of $\mathrm{Pb}^{2+}$ and $\mathrm{Cd}^{2+}$ ions in environmental waters," Measurement, vol. 140, pp. 81-88, 2019.

[219] A. Sánchez-Calvo, M. T. Fernández-Abedul, M. C. BlancoLópez, and A. Costa-García, "Paper-based electrochemical transducer modified with nanomaterials for mercury determination in environmental waters," Sensors and Actuators B: Chemical, vol. 290, pp. 87-92, 2019.

[220] M. Ghorbani, T. Pedramrad, M. Aghamohammadhasan, O. Seyedin, H. Akhlaghi, and N. Afshar Lahoori, "Simultaneous clean-up and determination of $\mathrm{Cu}(\mathrm{II}), \mathrm{Pb}(\mathrm{II})$ and $\mathrm{Cr}(\mathrm{III})$ in real water and food samples using a magnetic dispersive solid phase microextraction and differential pulse voltammetry with a green and novel modified glassy carbon electrode," Microchemical Journal, vol. 147, pp. 545-554, 2019.

[221] H. Fu, Q. Yin, H. Wang et al., "Target-triggered in situ autocatalysis in nanopore membrane for point-of-care testing of sub-nanomolar $\mathrm{Ag}^{+}$," Sensors and Actuators B: Chemical, vol. 287, pp. 290-295, 2019.

[222] S. Venkateswarlu, S. Govindaraju, R. Sangubotla, J. Kim, M.$\mathrm{H}$. Lee, and K. Yun, "Biosynthesized highly stable $\mathrm{Au} / \mathrm{C}$ nanodots: ideal probes for the selective and sensitive detection of $\mathrm{Hg}^{2+}$ ions," Nanomaterials, vol. 9, no. 2, p. 245, 2019.

[223] Y. Song, C. Bian, J. Hu et al., "Porous polypyrrole/graphene oxide functionalized with carboxyl composite for electrochemical sensor of trace cadmium (II)," Journal of the Electrochemical Society, vol. 166, no. 2, pp. B95-B102, 2019.

[224] R. Tekenya, K. Pokpas, N. Jahed, and E. I. Iwuoha, "Enhanced specificity and sensitivity for the determination of nickel(II) by square-wave adsorptive cathodic stripping voltammetry at disposable graphene-modified pencil graphite electrodes," Analytical Letters, vol. 52, no. 2, pp. 373-398, 2019.

[225] L. Liu, K. Zhang, and Y. Wei, "A simple strategy for the detection of $\mathrm{Cu}(\mathrm{ii}), \mathrm{Cd}(\mathrm{ii})$ and $\mathrm{Pb}$ (ii) in water by a voltammetric sensor on a TC4A modified electrode," New Journal of Chemistry, vol. 43, no. 3, pp. 1544-1550, 2019.

[226] M. Lu, Y. Deng, Y. Luo et al., "Graphene aerogel-metalorganic framework-based electrochemical method for simultaneous detection of multiple heavy-metal ions," Analytical Chemistry, vol. 91, no. 1, pp. 888-895, 2019.

[227] J. P. Devadhasan and J. Kim, “A chemically functionalized paper-based microfluidic platform for multiplex heavy metal detection," Sensors and Actuators B: Chemical, vol. 273, pp. 18-24, 2018.

[228] M. Finšgar, D. Majer, U. Maver, and T. Maver, "Reusability of SPE and Sb-modified SPE sensors for trace $\mathrm{Pb}$ (II) determination," Sensors, vol. 18, no. 11, article 3976, 2018.

[229] D. Wu, Y. Huang, S. Hu, X. Yi, and J. Wang, "Sensitive $\mathrm{Hg}^{2+}$ sensing via quenching the fluorescence of the complex between polythymine and 5,10,15, 20-tetrakis( $N$-methyl-4pyridyl) porphyrin (TMPyP)," Sensors, vol. 18, no. 11, article 3998, 2018.
[230] S. Wang, B. Lin, L. Chen et al., "Branch-migration based fluorescent probe for highly sensitive detection of mercury," Analytical Chemistry, vol. 90, no. 20, pp. 11764-11769, 2018.

[231] W. Cai, S. Xie, J. Zhang, D. Tang, and Y. Tang, "Immobilizedfree miniaturized electrochemical sensing system for $\mathrm{Pb}^{2+}$ detection based on dual $\mathrm{Pb}^{2+}$-DNAzyme assistant feedback amplification strategy," Biosensors and Bioelectronics, vol. 117, pp. 312-318, 2018.

[232] A. Aravind and B. Mathew, "Tailoring of nanostructured material as an electrochemical sensor and sorbent for toxic Cd (II) ions from various real samples," Journal of Analytical Science and Technology, vol. 9, no. 1, p. 22, 2018.

[233] X. Pang, L. Gao, H. Feng, X. Li, J. Kong, and L. Li, "A peptidebased multifunctional fluorescent probe for $\mathrm{Cu}^{2+}, \mathrm{Hg}^{2+}$ and biothiols," New Journal of Chemistry, vol. 42, no. 19, pp. 15770-15777, 2018.

[234] V. H. Dang, P. T. H. Yen, N. Q. Giao et al., “A versatile carbon fiber cloth-supported $\mathrm{Au}$ nanodendrite sensor for simultaneous determination of $\mathrm{Cu}(\mathrm{II}), \mathrm{Pb}(\mathrm{II})$ and $\mathrm{Hg}(\mathrm{II})$," Electroanalysis, vol. 30, no. 10, pp. 2222-2227, 2018.

[235] L. Wang, G. Jing, and T. Cui, "Nafion coated flexible bismuth sensor for trace lead and cadmium determination," Microsystem Technologies, vol. 24, no. 9, pp. 3697-3704, 2018.

[236] S. Tang, J. Sun, Y. Li et al., "pH-dependent selective ion exchange based on (ethylenediamintetraacetic acid- nickel)layered double hydroxide to catalyze the polymerization of aniline for detection of $\mathrm{Cu}^{2+}$ and $\mathrm{Fe}^{3+}, "$ Talanta, vol. 187, pp. 287-294, 2018.

[237] Q. Zhu, L. Liu, Y. Xing, and X. Zhou, "Duplex functional Gquadruplex/NMM fluorescent probe for label-free detection of lead(II) and mercury(II) ions," Journal of Hazardous Materials, vol. 355, pp. 50-55, 2018.

[238] W.-T. Tsai, M.-H. Nguyen, J.-R. Lai, H.-B. Nguyen, M.C. Lee, and F.-G. Tseng, "ppb-level heavy metal ion detection by electrochemistry-assisted nanoporous silicon (ECA-NPS) photonic sensors," Sensors and Actuators B: Chemical, vol. 265, pp. 75-83, 2018.

[239] P. Li, J. Li, M. Bian et al., "A redox route for the fluorescence detection of lead ions in sorghum, river water and tap water and a desk study of a paper-based probe," Analytical Methods, vol. 10, no. 26, pp. 3256-3262, 2018.

[240] J. Xu, X. Jie, F. Xie, H. Yang, W. Wei, and Z. Xia, "Flavonoid moiety-incorporated carbon dots for ultrasensitive and highly selective fluorescence detection and removal of $\mathrm{Pb}^{2+}$," Nano Research, vol. 11, no. 7, pp. 3648-3657, 2018.

[241] M. B. Gumpu, M. Veerapandian, U. M. Krishnan, and J. B. B. Rayappan, "Amperometric determination of As(III) and Cd(II) using a platinum electrode modified with acetylcholinesterase, ruthenium(II)-tris(bipyridine) and graphene oxide," Microchimica Acta, vol. 185, no. 6, p. 297, 2018.

[242] S. Liu, T. Wu, F. Li, Q. Zhang, X. Dong, and L. Niu, "Disposable graphene sensor with an internal reference electrode for stripping analysis of heavy metals," Analytical Methods, vol. 10, no. 17, pp. 1986-1992, 2018.

[243] M. Xiao, H. Shen, Q. Fu et al., "Practical immune-barometer sensor for trivalent chromium ion detection using gold core platinum shell nanoparticle probes," Analyst, vol. 143, no. 6, pp. 1426-1433, 2018.

[244] M. Sebastian and B. Mathew, "Ion imprinting approach for the fabrication of an electrochemical sensor and sorbent for lead ions in real samples using modified multiwalled carbon 
nanotubes," Journal of Materials Science, vol. 53, no. 5, pp. 3557-3572, 2018.

[245] L. Li, D. Liu, A. Shi, and T. You, "Simultaneous stripping determination of cadmium and lead ions based on the Ndoped carbon quantum dots-graphene oxide hybrid," Sensors and Actuators B: Chemical, vol. 255, pp. 1762-1770, 2018.

[246] W. Ren, Y. Zhang, and M. J. Li, "Sensitive determination of $\mathrm{Zn}^{2+}, \mathrm{Cd}^{2+}$ and $\mathrm{Pb}^{2+}$ at electrochemically reduced nanoporous graphene oxide/bismuth film electrode," International Journal of Electrochemical Science, vol. 13, no. 2, pp. 13311342, 2018.

[247] C. Topcu, G. Lacin, V. Yilmaz et al., "Electrochemical determination of copper(II) in water samples using a novel ionselective electrode based on a graphite oxide-imprinted polymer composite," Analytical Letters, vol. 51, no. 12, pp. 18901910, 2018.

[248] A. Zazoua, N. Khedimallah, and N. Jaffrezic-Renault, "Electrochemical determination of cadmium, lead, and nickel using a polyphenol-polyvinyl chloride-boron-doped diamond electrode," Analytical Letters, vol. 51, no. 3, pp. 336347, 2018.

[249] Z. Lu, J. Zhang, W. Dai, X. Lin, J. Ye, and J. Ye, “A screenprinted carbon electrode modified with a bismuth film and gold nanoparticles for simultaneous stripping voltammetric determination of $\mathrm{Zn}(\mathrm{II}), \mathrm{Pb}(\mathrm{II})$ and $\mathrm{Cu}(\mathrm{II})$," Microchimica Acta, vol. 184, no. 12, pp. 4731-4740, 2017.

[250] A. Maity, X. Sui, C. R. Tarman et al., "Pulse-driven capacitive lead ion detection with reduced graphene oxide field-effect transistor integrated with an analyzing device for rapid water quality monitoring," ACS Sensors, vol. 2, no. 11, pp. 16531661,2017

[251] Y. Zhang, H. Li, M. Chen et al., "Ultrasensitive electrochemical biosensor for silver ion based on magnetic nanoparticles labeling with hybridization chain reaction amplification strategy," Sensors and Actuators B: Chemical, vol. 249, pp. 431-438, 2017.

[252] D. Martin-Yerga, I. Alvarez-Martos, M. C. Blanco-Lopez, C. S. Henry, and M. T. Fernandez-Abedul, "Point-of-need simultaneous electrochemical detection of lead and cadmium using low-cost stencil-printed transparency electrodes," Analytica Chimica Acta, vol. 981, pp. 24-33, 2017.

[253] M. B. Gumpu, U. M. Krishnan, and J. B. B. Rayappan, "Design and development of amperometric biosensor for the detection of lead and mercury ions in water matrix-a permeability approach," Analytical and Bioanalytical Chemistry, vol. 409, no. 17, pp. 4257-4266, 2017.

[254] X. Qi, J. Qian, T. Chen, D. Lu, and B. Chen, "Electrochemical determination of $\mathrm{Cu}(\mathrm{II})$ ions based on $\mathrm{Ag} / \mathrm{Pd}$ alloy for water quality early warning," International Journal of Electrochemical Science, vol. 12, no. 6, pp. 5511-5520, 2017.

[255] J. Liu, G. Lv, W. Gu, Z. Li, A. Tang, and L. Mei, “A novel luminescence probe based on layered double hydroxides loaded with quantum dots for simultaneous detection of heavy metal ions in water," Journal of Materials Chemistry C, vol. 5, no. 20, pp. 5024-5030, 2017.

[256] L.-R. Popescu Mandoc, I. Moldoveanu, R.-I. Stefan-van Staden, and E. M. Ungureanu, "Pattern recognition of $\mathrm{Cu}(\mathrm{II})$, $\mathrm{Pb}(\mathrm{II}), \mathrm{Hg}(\mathrm{II})$, and $\mathrm{Cd}(\mathrm{II})$ in waste waters," Microsystem Technologies, vol. 23, no. 5, pp. 1141-1145, 2017.

[257] N. Youngvises, K. Suwannasaroj, J. Jakmunee, and A. AlSuhaimi, "Multi-reverse flow injection analysis integrated with multi-optical sensor for simultaneous determina- tion of $\mathrm{Mn}(\mathrm{II}), \mathrm{Fe}(\mathrm{II}), \mathrm{Cu}(\mathrm{II})$ and $\mathrm{Fe}(\mathrm{III})$ in natural waters," Talanta, vol. 166, pp. 369-374, 2017.

[258] G. Chen, J. Hai, H. Wang, W. Liu, F. Chen, and B. Wang, "Gold nanoparticles and the corresponding filter membrane as chemosensors and adsorbents for dual signal amplification detection and fast removal of mercury(ii)," Nanoscale, vol. 9, no. 9, pp. 3315-3321, 2017.

[259] W. Zhou, J. Ding, and J. Liu, "2-aminopurine-modified DNA homopolymers for robust and sensitive detection of mercury and silver," Biosensors and Bioelectronics, vol. 87, pp. 171$177,2017$.

[260] K. Tyszczuk-Rotko and K. Domańska, "Simple and sensitive voltammetric procedure for determination of $\mathrm{Cd}$ (II) and $\mathrm{Pb}$ (II) using bismuth-coated screen-printed carbon electrode prepared with mediator," Journal of the Electrochemical Society, vol. 164, no. 7, pp. H537-H544, 2017.

[261] M. B. Gumpu, M. Veerapandian, U. M. Krishnan, and J. B. B. Rayappan, "Simultaneous electrochemical detection of $\mathrm{Cd}(\mathrm{II}), \mathrm{Pb}(\mathrm{II}), \mathrm{As}(\mathrm{III})$ and $\mathrm{Hg}(\mathrm{II})$ ions using rutheniu$\mathrm{m}(\mathrm{II})$-textured graphene oxide nanocomposite," Talanta, vol. 162, pp. 574-582, 2017.

[262] P.-H. Chen, C. Lin, K.-H. Guo, and Y.-C. Yeh, "Development of a pigment-based whole-cell biosensor for the analysis of environmental copper," RSC Advances, vol. 7, no. 47, pp. 29302-29305, 2017.

[263] B. Bansod, T. Kumar, R. Thakur, S. Rana, and I. Singh, "A review on various electrochemical techniques for heavy metal ions detection with different sensing platforms," Biosensors and Bioelectronics, vol. 94, pp. 443-455, 2017.

[264] D. Omanović, C. Garnier, K. Gibbon-Walsh, and I. Pižeta, "Electroanalysis in environmental monitoring: tracking trace metals-a mini review," Electrochemistry Communications, vol. 61, pp. 78-83, 2015. 